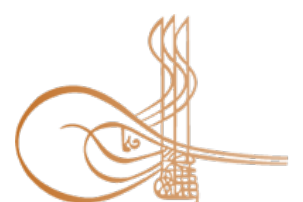

www.turkishstudies.net/social
Turkish Studies - Social Sciences

eISSN: 2667-5617

Research Article / Araştırma Makalesi

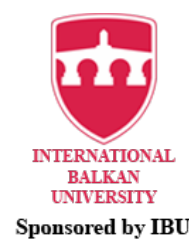

Sponsored by IBU

\title{
Simülakr Bir Özne Olarak Bedenin İnşası (Bu Ben miyim?- Doktor B Örneği )
}

Building the Body as a Simulakr Subject (Example of Is this me? - Doctor B.)

\author{
Adem Sağır ${ }^{*}$ - Merve Özdemir ${ }^{* *}$
}

\begin{abstract}
Many expressions were put forward on the body and body appearances from past to present and it was tried to create the ideal body perception in individuals through these expressions. Individuals on the other hand started to build their own bodies and personalities with these ideal body perceptions. In the World of today surgical interventions on the body were added to the process of building and by banalization it was started to be reflected as a reality that should be ordinary. Idealized body perceptions are reflected to individuals especially women, directly or indirectly by mass media. In the study, "the effects of ideal body perception on identity building as a simulated subject" were obtained as a problem. In this context, the purpose of this study was to research the effects of TV programs on the body of individuals, especially women, during the construction of identity as a simulated subject. Similarly, it was handled why the female body is brought to the fore more than the male bodies in the TV programs based on body building. It was also aimed to examine the subjects such as whether individuals are exposed to the ideal body reality or have surgical interventions which is thought to be necessary and whether there is the fashion of body or not. Within this scope, the TV program named "Is this me?" was selected as a sample. While this program builds the areas where the participants are disturbed by surgical interventions, it also carries out an identity building through the body. During the research process, the TV program named "Is this me?" was aimed to be examined in the direction of Content and Discourse Analysis. The program was handled in four categories such as "stigmatization", "perfect body perception", "emotion management", "display and concealment value".
\end{abstract}

\section{Structured Abstract: Introduction}

Television continues to maintain its absolute power. One of the main factors that make television so powerful is that its programs continue to affect large audiences as a discourse. It is seen that Doctor B. has such a format in terms of being the subject of this study. Doctor B. is also important in terms of referring to the transforming face of the television. Undoubtedly while digitalization is the basic process that turns television into a mutant, it also turns the television subject into a simulated subject. Simulated subject comes up with variable answers to the question of who I am. It is the active subject of the digital field and has a constantly renewing strength to build itself. What makes the subject of Doctor B. simulated subject is that he has the power and responsibility

\footnotetext{
${ }^{*}$ Doç. Dr. Karabük Üniversitesi Edebiyat Fakültesi Sosyoloji Bölümü

Assoc.Prof., Karbuk University, Faculty of Letters, Department of Sociology

ORCID 0000-0003-0763-0518

ademsagir@karabuk.edu.tr

** Lisans Öğrencisi, Karabük Üniversitesi Edebiyat Fakültesi Sosyoloji Bölümü undergraduate, Karabuk University, Faculty of Letters, Department of Sociology

ORCID 0000-0003-0483-4152

ozdm.merve0320@gmail.com
}

Cite as/ Atıf: Sağır, A., Özdemir, M. (2020). Simülakr bir özne olarak bedenin inşası (bu ben miyim?- Doktor B Örneği

). Turkish Studies - Social, 15(4), 2113-2140. https://dx.doi.org/10.29228/TurkishStudies.42670

Received/Geliș: 27 March/Mart 2020

Accepted/Kabul: 20 June/Haziran 2020

Copyright $($ INTAC LTD, Turkey
Checked by plagiarism software

Published/Yayın: 25 June/Haziran 2020

CC BY-NC 4.0 
to make the changes he wants on his body. The location of the subject shown to him in the computer program is the same as the subject who changes the photo he took on his smartphone by playing on it. As one is the active agent of plastic surgery, the other is passive but is a powerful module that represents the identities transformed by social media. This study examined the program named "Is this Me?" (Doctor B.). While making the examination, the concept of simulated subject was used and was focused on how the principles of digitalization affect daily life. In the study, Doctor B. was accepted as a discourse text and subjected to discourse analysis. It is possible to underline the main titles emerging in this analysis as follows.

\section{Theroretical Framework}

Is it me? (Doctor B) " The discourses of the individuals that participated in the television program named "Is this me? (Doctor B) "about ideal body appearance were evaluated under the sub-headings such as their ideal and perfect body definitions, harming the body / health in order to reach the ideal body appearance and referring to gender roles over the body. When the discourses used in the program are analyzed totally, it was seen that the ideal body perception is not uniform and each participant has a different ideal body perception created for themselves. But these different perceptions were influenced by social discourses and eventually became a common image that is approved by everyone. The ideal body perception that occurs in the minds of the individuals participating in the program was generally defined through the parts they do not like or lack in their own bodies. In this context, "Is It Me?" It was seen that the following points drew attention about the ideal body appearance in the discourses of the participants of "Is this Me?".

While all individuals participating in the program have a real health problem, also have strong aesthetic concerns. For example, after their health improves, women who had one breast removed because of cancer, need surgical intervention to correct the deficiency that impairs their ideal body perception. In another section, the male participant, who had a nose surgery to breathe does not want any aesthetic correction in his nose. However, the male participant comes up with difficulties in social life due to his appearance. The statement of participant that "I am happy but people do not accept me" is an important inference in terms of the effect of the social field on the participants. The self-esteem of individuals participating in the program is completely related to their body appearance. It is possible to evaluate self-confidence as an identity criterion. Within this scope, individuals who are lack of self-confident before surgery become self-confident people after the operation. Surgery redefines its social positions as rebirth. The basic context that comes out in this part of the study is the changing of the identity criteria. Therefore if self-confidence changes in connection with body appearance, identity features can also change depending on body appearance. Thus, the construction of a new identity takes place through the body.

\section{Method}

In the study, "the effects of ideal body perception on identity building as a simulated subject" were obtained as a problem. In this context, the purpose of this study was to research the effects of TV programs on the body of individuals, especially women, during the construction of identity as a simulated subject. Similarly, it was handled why the female body is brought to the fore more than the male bodies in the TV programs based on body building. It was also aimed to examine the subjects such as whether individuals are exposed to the ideal body reality or have surgical interventions which is thought to be necessary and whether there is the fashion of body or not. Within this scope, the TV program named "Is this me?" was selected as a sample. While this program builds the areas where the participants are disturbed by surgical interventions, it also carries out an identity building through the body. During the research process, the TV program named "Is this me?" was aimed to be examined in the direction of Content and Discourse Analysis. The program was handled in four categories such as "stigmatization", "perfect body perception", "emotion management", "display and concealment value".

\section{Finding and Discussion}

In data analysis strong contexts related with social gender were found out. In order to be a woman, it is necessary to have the appearance of a woman accepted by the society. In other words, it is not only enough to be a woman by gender, but also to have a waist and hip fold. While many of the men participating in the program complain that their appearance is similar to that of the female body, many women are also uncomfortable that their appearance is similar to that of the male body. In other words, the body shapes of men and women are clearly determined by the society and separated from each other. The bodies that cannot create this distinction sufficiently disrupt the appearance of ideal male and ideal female body. Another problem 
women experience over the body is that they feel themselves insufficient in other words inadequate. The main reason for feeling incomplete is that they see their own bodies far from ideally determined body patterns. Therefore, it is possible to state that women feel bad both towards their spouses and their children. As a result of this anxiety, it is seen that they think that they cannot fill the concepts of "exact mother" or "exact wife". Individuals are assessed and stigmatized by their appearance. This stigmatization process is generally embodied by the fact that individuals are remembered with some nicknames and mocked over their appearance. In the discourses of the individuals, we often see the expression "like an elder". Seeming old at the young age makes people uneasy because old age is built as a reality that should be postponed rather than desired. Another result related to this acceptance in data analysis is the idea that surgical intervention on the body will always affect the life of people positively. People think that at the end of the operations their lives will also change with their body appearance. Two people stated that although they were happy their images, people do not accept it. This situation shows that the effect of society on body attitudes is quite strong.

The reason for asking the question "Is this Me?" is that the individuals who underwent surgery see a different image which is a different body when they first look at the mirror. This new body that surprises even its owner in the mirror, brings with a new identity. In other words, surgeries perform identity building as well as body building. In individuals there is an attempt to hide the parts they dislike in their body appearance and not to show anyone with this disliked part. This hiding value also affects the social lives of individuals. Because in individuals the desire of hiding occurs when they come together with other people. This situation affects the healthy communication of individuals with other people as well as their own lives negatively. Body appearance also affects the emotions of people very much. Individuals who do not have a generally approved ideal body appearance are in an introverted and unhappy mood while the ones with an ideal body appearance have a happier and positive mood. In other words in the program process having an ideal body is actually shown as a prerequisite for happiness.

Keywords: Sciology, Identity, Body, Simulakr Subject, Doktor B., Stigma.

Öz: Beden ve beden görünümleri üzerine geçmişten günümüze birçok söylem ortaya konulmuş ve bu söylemler aracılığıyla bireylerde ideal beden algısı oluşturulmaya çalışılmıştır. Bireyler ise bu ideal beden algılarıyla kendi beden ve kişiliklerini inşa etmeye başlamışlardır. Günümüz dünyasında inşa edilme sürecine beden üzerinde yapılan cerrahi müdahaleler de eklenmiş ve idealleştirilmil bir gerçeklik şeklinde yansıtılmaya başlanmışıır. İdealize edilmiş beden algıları bireylere özellikle de kadınlara doğrudan veya dolaylı şekillerde kitle iletişim araçları ile çeşitli şekillerde sunulmaktadır. Çalışmada "ideal beden algısının simülakr bir özne olarak kimlik inşasına etkileri" problem olarak belirlenmiştir. Bu bağlamda araştırmada simülakr bir özne olarak kimlik inşası ve bu inşa sürecinde TV programlarının bireylerin özellikle de kadınların bedenleri üzerindeki etkilerinin incelemesi amaçlanmıştır. Ayrıca beden inşası üzerine kurgulanan TV programlarında kadın bedeninin erkek bedenine göre neden daha fazla ön plana çıkarıldığı da ele alınmıştı. Bireylerin olması gerektiği düşünülen ideal beden gerçekliği imajlarına maruz kaldıkları için mi yoksa gerçekten bedenlerine sağlık açısında bir müdahale olmasıl gerektiği için mi cerrahi müdahaleye başvurdukları ve bedenin modasının olup olmayacağının tartışılması da amaçlanmıştır. Bu kapsamda araştırmaya "Bu Ben Miyim?" adlı TV programı örneklem olarak seçilmiştir. Bu program katılımcıların bedenlerindeki rahatsız oldukları yerleri cerrahi müdahaleler ile inşa ederken beden üzerinden bir kimlik inşasını da gerçekleştirmektedir. Araştırma sürecinde "Bu Ben Miyim?" adlı TV programının İçerik ve Söylem Analizi doğrultusunda incelenmiştir. Program içeriği "damgalama", "kusursuz beden algısı", "duyguların yönetimi", "sergileme ve gizleme değeri" gibi dört kategori çerçevesinde analize tabi tutulmuştur.

Anahtar Kelimeler: Sosyoloji, Kimlik, Beden, Simülakr özne, Doktor B., Damga.

\section{Giriş}

Güzellik endüstrisinin anlatıldığı ve özneye bakışıyla ön plana çıkan Nip/Tuck dizisi "nerenizi beğenmediğinizi söyleyin?" sorusuna verilen "görünüşümden hep mutsuz oldum" yanıtıyla başlamaktadır. Nip/Tuck bölümler boyunca farklı biçimlerde kullandığı felsefi tartışmalardan estetik ameliyatlarla değiştirdiği bedenlere kadar, güzellik endüstrisinin beden inşa 
sürecini betimlemektedir. Uzman doktoralara teslim olan beden için söz söyleme hakkı kişinin kendisinden çok mekânı inşa eden profesyonel kurallara bırakılmıştır. Bedenin üzerindeki kontrol gücünün kimde olduğu sorusu günümüzde en sık tartışma konularından birisidir. Kadın ve erkekler için geçerli olmaya başlayan "nasıl bir görünüme sahip olunması gerektiği” konusunda çok fazla söylem bulunmaktadır. Bu söylemler özellikle bedenin tanımlanması ve bedenin görünümü üzerinden yapılmakta ve sıklıkla da kadınlara dönük olarak yoğunlaşmaktadır. Söylemin merkezinde beğenilerin beden üzerinden inşa edilmesine dair perspektifler yer almaktadır. Günümüzde iletişim araçlarının da sürece dahil olmasıyla bahsi geçen perspektifler, bedenin ideal tiplerle örüntülenmesi gerekliliğini sürece eklemlemiştir. Vücut ölçüleri, yüzün şekli, göğüs büyüklügü, dudak ölçüleri, makyaj, kıyafet ve saçın olması gerektiği biçimlerine dair söylemler, iletişim araçlarıyla yeniden üretilmektedir. Bu bağlamda reklamlar, TV programları, diziler ve sosyal medya bedenin ideal biçimlerinin ne olması gerektiğine dair ölçütleri bireylere sunmaktadır. Bireyler yaşamlarının her alanında karşılaştıkları bu söylemlerle idealize edilmiş beden algısına sahip olmakta ve bu bedene ulaşabilmek için de birçok süreç geçirmektedirler.

Gündelik hayat, toplumsal etkileşimler ve toplumla kurulan ilişkiler kişinin kimliğini inşa ettiği, benlik algısını kurduğu temel alanı tanımlamaktadır (Goffman, 2016; Bennett, 2018). Kimlik inşası ve benlik algısının beden üzerinden nasıl bir süreç izlediği bu çalışmanın odak noktası olmuştur. Çünkü beden üzerindeki kontrol ve inşa talebi hem modern hem de postmodern bağlamlarıyla hala güncelliğini korumaktadır (Foucault, 2015; Sennett, 2019 Soyşekerci, 2015; Özmakas, 2018; Bingöl, 2017; Tekin, 2016). Beden üzerindeki egemenlik hakkının kime ait olduğu, dinsel baskılar, politik olarak yaşam ve ölümün söylem aracı olarak kullanılması dahil birçok bağlam, günümüzün bedenle ilgili tartışmalarının önemli bir parçasını oluşturmaktadır. Bu bağlamda beden hala çok güçlü argümanlarla sosyolojik tartışmaların merkezinde olma özeliğine sahiptir. Beden "her türlü toplumsal sürecin bir uzantısı olarak" (Connell, 1998:114) belirmektedir. Simulakr öznenin anlamı ve beden ile simulakr özne ilişkisinin ne kadar önemli bu çalışmada önemli bir alt başlık olarak kullanılmıştır.

Simulakr özne kavramı ilk olarak Sağır ve Aktaş'ın(2019) hazırlamış oldukları bir çalışmada sosyal medyanın yarattığı özneye atıf yapmak için kullanılmıştır. İçerik olarak da sosyal medyada kimliğin kurulma biçimini ifade etmektedir. Sosyal medya aynı zamanda simulakr öznenin hikayesinin başladığı yerdir. Sağır ve Aktaş'a göre simulakr özne kendisine yeni bir kimlik ve beden ikamesini sosyal medya üzerinde yapmaktadır. Simulakr özneinin sahip olduğu modüler kimliğin bir tarafi her zaman sahnede olmaya hazırdır. Sağır ve Aktaş, sanal vitrin kavramını açıklarken Goffman (2016)'ın vitrin kavramına içkin "bireylerin gündelik hayatta diğer bireylere kendilerini nasıl sunduğu” ve Debord (1996)'un gösteri toplumunu ifade ederken kullanmış olduğu "yaşanmış ve yaşanılacak olan her şeyin yerini bir temsile bırakması" söylemine atıf yaparak açıklamışlardır. Sağır ve Aktaş'ın çalışmasında vurgu yaptığı gibi vitrin ve temsil simulakr özneye sabit olmama özelliği yüklemektedir. Bu kapsamda simulakr özne için uzakta olmanın bir önemi yoktur. Aynı anda her yerde var olabildiği gibi onun erişilmez bir yönü de bulunmaktadır. Simulakr özne bu erişilmezliği, kendisine temas edildiğinde yeniden şekil değiştirmekle gerçekleştirir. Simulakr özne bugünün insanının kimlik tipolojisidir. Simulakr öznenin sabitliği ortadan kalkmıştır. Gündelik hayatın sunulduğu sahnelerde üzüntülerin, mutlulukların, giyilen kıyafetlerin, yemeklerin lezzetinin deneyimlenmesi onun için kolaydır. Çünkü dijital çağın insanları için mesafelerin niceliğinin bir önemi yoktur. Simulakr öznenin bu haliyle tıpkı bir hayalet gibi olduğunu söylemek mümkündür. Simulakr öznenin hayalet olması, sosyal medyada etkileşime girilen kişinin gerçekte kim olduğunun tam olarak bilinemeyeceği kaygısının belirsizliğiyle ilişkilidir. Etkileşim halindeki kişinin gerçekte kim olduğu sorusu, simulakr öznenin en temel kafa bulanıklı̆̆ıdır.

Maskeler, avatarlar, simulakr özneyi görsel bir inşa biçimi olarak düşündüğümüz zaman sosyal medya araçlarında kullanılan fotoğraf düzenleyiciler, akılı telefonlardaki popüler eklentiler, güzellik endüstrisinin bedeni organize ettiği alanlarla aynı kaygılardan beslenmektedir. Şöyle ki 
bedende nereyi beğenmediğini söylemek bir sonraki adımda bedende nereye müdahale edileceği sorusunu akla getirmektedir. Sosyal medyanın narsizm kültürü benzer şekilde özneye sunduğu araçlarla bedeninde beğenilmeyen yerleri özellikle yüz bölümüne dokunmayı müdahale etmeyi ve değiştirtmeyi kolaylaştırmaktadır (Alanka ve Cezik, 2016; Atay, 2017; Akkaş vd., 2020; Buffardi ve Campbell, 2008; Carpenter, 2012; Çaycı vd., 2019; Lee ve Sung, 2016; Oğuz, 2016). Bu bağlamda simulakr özne, programların size nasıl görünmek istediğiniz hayalini somutlaştırmaktadır. Sivilceyle oynama, yüz kırışıklığını giderme, kendini zayıf gösterme daha kaslı görünme ve biraz daha abartıldığında saç rengi bile değiştirilebilmektedir. Bütün bunların hepsi iletişim teknolojileri veya uygulamalar yardımıyla herhangi bir ücret gerektirmemektedir. Böylece herkes kendi güzellik uzmanı haline gelmektedir. Böylece simulakr öznenin kendine özgü bir uzmanlığı oluşmakta ama bu uzmanlık sadece ona değil, kitleselliğe özgü bir yönüyle görünür olmaktadır. Bu süreç aynı zamanda özerk olarak simulakr öznenin kendisine bir alan oluşturmasını da içermektedir. Kuşkusuz Manuel Castells'in (2016) kitlesel öz iletişim içerisinde tanımladığı özerklik alanı bu süreci betimlemektedir. Simulakr özneyi bu anlamda bu özerk alanda kendisini biricikleştirmesi bağlamında değerlendirmek mümkündür. Ancak simulakr öznenin gerçekle bağını koparttığını da ifade etmek gerekir. Gerçekle bağını kopartmasını sağlayan ona sunulan teknik firsatlardır. Teknik bilgi bu anlamda bedeni dönüştürmekte, onu yeniden inşa etmektedir ve yerini öznenin yorumlanmasına bırakmaktadır. $\mathrm{Bu}$ durum tıpk1 güzellik endüstrisi içerisinde bedenin inşa edilmesi gibidir (Paguet, 2015; Yıldırım ve Demir, 2018; Çizmeci ve Güzel, 2018; Crary, 2015).

Doktor B'nin ameliyat öznesi olan kişiye bilgisayar programında ameliyat sonrasında nasıl görüneceğini göstermesi kişinin nasıl olacağı sorusuna verilen somut yanıttır. Bireyler teknolojik araçlar sayesinde kendilerini görmekte ve kendileriyle ilgili yeni bir süreci doktorla işbirliği içerisinde inşa etmektedirler. Bu anlamda teknoloji gözün çerçevesini ve sınırlarını belirlemektedir. Optiklerin icat edildiği dönemlerdeki gibi gözün anlamı ve gözün görme becerisini değiştirip ona yeni anlamlar yüklemektedir (Crary, 2015; Soyşekerci, 2015; Sontag, 2008). Bilgisayar ekranında gelecekteki görüntüsüyle muhatap olan özne, gerçek görüntüsüne yabancılaşmaktadır. Bu anlamda kodların insanın suretini de ele geçirdiğini söylemek mümkündür. Böylece maskeyi icat eden makineyken makine de kişinin görüntüsünü yaratmaktadır. Estetik ameliyatlarda o görüntünün dışa çıkartılmış hali olmakta, kodların tasarladığı beden de bir sonraki adımda ameliyatın gerçeğe dönüştürdüğü bedene dönüşmektedir. Doktorlarsa her zamanki gibi mesleki uzmanlık bilgileriyle olaya müdahil olmaktadır. Simulakr öznenin sosyal medyada kendine yaptığı müdahaleler, parası olan için estetik ameliyatlarda başka bir formata girmektedir. Tabi ki burada önemli detaylardan birisi bireylerin ameliyat tercihlerinde bulunurken ya da ameliyat olacakları mekâna geldiklerinde ne istediklerinin farkında olmalarıdır. Bu farkındalığın oluşmasında toplumsal beklentiler etkili olmaktadir.

\section{Ben Kimim'den Bu Ben Miyim Sorusuna}

Bedenin niçin önemli olduğu sorusu, aslında gündelik hayatta öznenin sahip olduğu kimliğin büyük bir parçasını içeriyor olmasıyla ilişkilidir (Bilgin, 2016: 220). Geleneksel dönemlerde kimlikler toplum aracılığıla bireylere aktarılırken modernleşmeyle birlikte bireyler kendi uygun gördükleri şekillerde kimliklerini belirleyebilmektedirler (Avcıoğlu, 2011: 359). Günümüz toplumlarında ise başkalarının gözünde değerli olmak, tanınmak ve onaylanmak büyük ölçüde bireyin beden görünüşü üzerinden gerçekleşmektedir. $\mathrm{Bu}$ nedenle beden ile "kimlik algısl" birbirinden bağımsız düşünülebilecek kavramlar değildir. Çünkü "insanlar beden tiplerine göre çevrelerindeki bireyleri tanımlamakta ve bu beden tiplerine bağll olarak belli karakter özelliklerinin oluştuğunu varsaymaktadırlar" (Okumuş, 2009: 11). Ayrıca beden toplumla doğrudan ilişkisi olmas1 bakımından sosyal faktörler tarafindan sürekli inşa edilmekte (Giddens, 2000: 126; Turner, 2001) ve bireysel kimliklerin ötesine geçmektedir. Böylece sosyal bir aktör olarak insanın toplumda bulunmasıyla bedenini kullanması arasında sıkı bir bağ vardır. Yani insan bedeni aracılı̆̆ıyla toplum sahnesine çıkmaktadır. Bu nedenle de beden insanın insan olarak görünebilme aracıdır (Okumuş, 
2009: 2-3). Durkheim'in intihar konusundaki yaklaşımında olduğu gibi beden de sosyal bir olgu ve şey gibi düşünülebilir. Dolayısıyla beden biyolojik bir gerçeklik olduğu kadar aynı zamanda da sosyal ve kültürel bir gerçekliktir (Çak1, 2015: 307). Bu bağlamda beden, ilk bakışta sadece biyolojik bir yapı gibi görülse de aslında kültürel, sosyal ve politik olanla da ilintilidir. Moda, imaj, giyim tarzı, saç, cinsellik gibi bedene eklemlenebilecek bütün unsurlar politik, sosyal ve kültürel olanın izlenebileceği faktörlerdir (Tekin, 2015: 526; Okumuş, 2009: 5). Bu bağlamda beden, toplumsal olarak yapılandırılmış bir gerçeklik olarak değerlendirilebilir. Mauss (1979), bedenin sergilediği en küçük hareketlerin dahi kaynağında toplumsal bir nedenin olduğunu düşünmektedir. Mauss'a göre yürümek eylemi bile fiziksel zeminde gerçekleşiyormuş gibi görünse de her toplumdaki bireyler dolayısıyla da bedenler yürümek eylemini içinde bulunduğu toplumsal bağlamlarla öğrenmektedirler. Benzer şekilde Parsons, toplumsal eylem kuramında insanların bedenlerine bazı atıflarda bulunmuş ve insan bedenini toplumsal sistem ile eylemsel çevreye ait bir parça olarak değerlendirmiştir. Giddens'da benzer bir şekilde insanların bedenlerini, zaman ve mekan gerçekliklerinin bireylerin eylemlerini belli şekillerde sınırlamasının bir biçimi şeklinde görmüştür (Cirhinlioğlu ve Cirhinlioğlu, 2015: 403). Bock (2001: 270) ise bireyin hem kimlik duygusunun hem de dinamik bir yapı olan benliğinin süregelen bir toplumsal etkileşimlerle beden üzerinden inşa edildiğini söyleyerek aynı bağlamı güçlendirmektedir.

Sergilenen davranışlar ve beden görünümleri arasında da sıkı bir ilişki bulunmaktadır. Yani bazı davranışlar örneğin sesli şekilde ağlayıp kederlenmek vb. bazı bedenlere yakıştırılırken bazı bedenlere ise yasaklı bir konumdadır. Çünkü insanların algılarında hangi beden görünümünün hangi davranışı sergileyebileceği belirlenmiştir. Bu davranış kalıplarının dışına çıkan bedenler ise toplum tarafindan yargılanmaktadır:

\begin{abstract}
"David ellerini alnına dayamış, odayı bir ileri bir geri adımlıyordu. Aldığı haber onu serseme çevirmişti. Uzun bir süre buna inanamadı. Sheila onu aldatmış mıydı yani? Mümkün değildi! Fakat sonra her şey bir anda aydınlandı ve David gerçeği olanca dehşetiyle gördü. Bu kadarı fazlaydı. Bir gözyaşı nöbetiyle kendini yere attı (...) okuyunca o zaman da düşünmüştüm. Yani siz de görüyorsunuz. İnsanlardan bazılarından- böyle davranışlar bekleniyor. Ya benim gibilerden? Hilda'nın bir hafta sonunu biriyle geçirdiğini düşünün kendimi bir gözyaşı nöbetiyle yere atar mıyım? Benden bunu bekleyen bir kişi bile çıkar mı? Böyle bir kalıpla hayır. Kepazeliğin daniskası olur." (Orwell, 2015: 28)
\end{abstract}

Orwell'in kitabındaki karakter beden görünümünü "iğrenç derecede şişman dediklerinden değilim sadece biraz genişim ve kalaslığa meyleden bir yapım var" şeklinde tanımlar. Burada Orwell öncelikle bir pasaj verir ve o pasajdaki karakterin sergilediği davranışı kitabın asıl karakterine beden görünümünden dolayı yakışmayacağını savunur. Yani hangi bedenin hangi davranışı sergileyeceği aslında belirlenmiş bir gerçekliktir. İnsanlar da günlük hayatlarında kendilerine belirlenmiş olan davranışları sergilerler.

Beden görünümü bireylerin her dönemde kendilik dolayısıyla da kimlik algılarını etkilemektedir. Bireyde olumsuz beden imajının oluşması kendisine duyduğu saygının azalmasına, sosyal ilişkilerden çekilmesine ve kişilik gelişiminde aksaklıklara neden olabilmektedir (Beyazyüz ve Göka, 2015: 375). Aynı zamanda "bireylerin kendi zihinlerinde de bir beden imgesi, imajı vardır bundan hoşnut olup olmaması kendisine verdiği değeri etkilemektedir ve kişinin kendisini nasıl hissettiği önemli ölçüde bedeni ile ilgilidir" (Bilgin, 2016: 220). Beden üzerinde yapılan ya da yapılmak istenilen değişiklikler de büyük ölçüde bireylerin kendi beden görünüşlerini beğenmemelerinden veya bu görünüşlerinden tatmin olmamalarından kaynaklanmaktadır. Bu durum sonraki süreçte bireylerin kendi bedenleri üzerinde kontrol haklarını kullanmaları için yeni bir süreç ortaya çıkarmaktadır. Birçok iletişim kanalıyla ve toplumsal etkileşimle beslenen idealize edilmiş beden algısı, sürecin yönlendirici motivasyon kaynağı olmaktadır. İdeal beden algısıyla bireyler kendi bedenlerini olması gerektiği düşünülen kalıplara sığdırmak için yeniden üretmekte ve bu yolla 
da aslında kimliklerini sürekli inşa etmektedirler (Ersöz, 2010: 46). Bu inşa sürecini ise genelde kitle iletişim araçları özelde ise TV programları yönlendirmektedir. Özellikle kadın bedenine dönük oluşturulan TV programları aracılığı ile kadınlar açık veya örtük bir şekilde tasarlanmış ve idealize edilmiş beden algılarını içselleştirmiş ve bu doğrultuda bedenlerini değiştirmeye yani inşa etmeye başlamışlardır. Bu noktada ise çağdaş toplumlarda erkek bireylerin güç ve başarılarıyla kadın bireylerin ise çekiciliğiyle değer görmesi nedeniyle kadınların beden imajlarını erkeklere göre daha fazla sorunsallaştırdıklarını (Çakı, 2015: 309) söylemek mümkündür. Çünkü artık bir gösteri dünyasında yaşanmaktadır ve bu dünya aynı zamanda bahsedilen araçların sunduğu imajlar çağının da habercisidir. Bu noktada beden gösteri ve imaj kültürünün etkili bir şekilde sürdürülebilirliğini sağlamaktadır. İmaj kültürü aynı zamanda kapitalizmin beden üzerindeki gücünü göstermesi bakımından da dikkate değerdir (Solmaz, 2018: 625). Çünkü imajlar bireyleri dıș görünüm, bedensel inşa konusunda duyarlı hale getirmektedir. Bu durum aynı zamanda imaja yapılan vurgunun beden üzerinden tüketimi artırdığına da gönderme yapmaktadır (Featherstone, 2013: 179). Foucault'a göre de kapitalizmle birlikte beden, artık daha dikkate değerdir, sembolleştirilmiştir ve ön plandaki aktöre dönüşmüştür (2003: 157).

İdeal beden söylemleri kadınların kendi bedenlerine karşı memnuniyetsiz olmalarına neden olmaktadır (Ersöz, 2010: 46). Bu memnuniyetsizlik ise kadınların kendi beden görünüşlerinden tatmin olmamalarına dolayısıyla da bedenlerinin imajının bozuk olduğu yargısına sahip olmalarına neden olmaktadır. Beden imaj bozukluğu (Vücut Dismorfık Bozukluğu- Dismorfobi), kişinin fiziksel bir kusuru olmadığı veya hafif derecede bir fiziksel kusuru olduğu halde bu durumla zihinsel olarak aşırı derecede meşgul olmasıdır. Yani kişinin görünüşünün normal veya kabul edilebilir normal olmasına rağmen kendisini bedensel olarak kusurlu, çirkin ve eksik hissetmesine neden olan bir algılama bozukluğudur (Önder, 2018). Bireylerin beden görünümlerinin bozuk olduğu düşüncesine sahip olup dış görünüşlerinden memnun olmamalarının birçok nedeni bulunmaktadır. Bu nedenlerin başında ise kitle iletişim araçlarıyla bireylere aktarılan idealize edilmiş beden algıları gelmektedir. $\mathrm{Bu}$ idealize edilmiş beden algıları bireylerin erişmesinin ne kadar kolay olduğu bir mükemmellikte sunulmakta ve gündelik hayatın her alanında yaygınlaştırılmaktadır. Bu durum bireylerin kendi bedenleri ile idealize edilmiş beden görünümlerini kıyaslamalarına neden olmaktadır. Bu kıyaslama sonucunda ise bireyler kendi beden görünümlerinin kusurlu ve yetersiz olduğu düşüncesine kapılmaktadırlar. Bedeni hakkında bu gibi bir düşünceye sahip olan bireylerde özgüven yetersizliği ve içe kapanma davranışları oluşmaktadır. Bu durum ise bireylerin gündelik hayatta başka insanlarla sağlıklı ilişkiler kurmasını engellemekte ve bireyi her geçen gün daha fazla yalnızlaştırmaktadır (Sarıkaya, 2015). Bedeniyle barışık olmayan özneye toplumsal ilişkilerin yaptığı baskı da dikkate değerdir. Sosyal damgalama burada devreye girmekte ve birtakım etiketlemelerle kişinin bedeniyle ilgili olumsuz yargılar edinmesinde etkili olmaktadır. Sonrasında kadınlar vücutlarındaki rahatsız oldukları kısımları estetik ameliyatlarına başvurarak gidermeye çalışmakta ve bu durum giderek sıradanlaşmaktadır. Kadının yaşadığı bu ruhsal boyutu Deniz (2019: 6) şu şekilde betimlemektedir

\footnotetext{
“Toplumsal olarak kabul edilmiş güzellik görünümüne sahip olmamak bireylerin gündelik hayatında sosyalleşememe ve kendisini diğer bireylere göre eksik hissetme gibi bazı sorunlar yaşamasına neden olabilmektedir. Bu durum bireyin kendi bedenini kendi varoluşuna bir tehdit olarak görmesine ve hayatıyla ilgili riskleri göze alarak sonu ölümle neticelenebilen estetik amaçlı ameliyatlara başvurmasına neden olabilmektedir."
}

Ersöz’ün (2010: 46) ideal kadın bedeniyle ilișkili tarihsel sürecin İkinci Dünya Savașına kadar götürüldüğünü ifade etmektedir. 1950’lerde ideal kadın bedeni kiloludur. Çünkü bu tarihlerde ideal beden konusunda balıketli ya da şişmanlık gözdedir. 1990'l y yllarda ideal beden kilosu 50'lere kadar düşer. İdeal kadın bedenine dönük algının ise 1960'lı yılların sonunda değişmeye başladığı görülmektedir. Başka dönemlerde yaş ve şişmanlık statü göstergesi iken, günümüze kadar gelen süreçte ise güzellik incelikten ve zayıflıktan ayrılmaz olmuştur. Kuşkusuz bu sürecin değişim ve dönüşümünde kitle iletişim araçlarının önemli bir fonksiyon üstlendiğini söylemek mümkündür. 
Kitle iletişim araçlarındaki ideal beden algısını oluşturma çabası her zaman açık şekillerde olmayıp örtülü şekillerde de gerçekleştirilebilmektedir. Bu doğrultuda TV programlarında ideal bedene sahip olan ve olmayan kadınların nitelendirildiği sıfatlar ve çevrelerinde gördükleri muameleler de örtük olarak ideal beden algısını oluşturmaktadır (İmren, 2018: 106). Dolayısıyla içinde bulunduğumuz koşullarda ideal beden algısının dayatılması en fazla genelde kitle iletişim araçları özelde ise TV ekranlarından gerçekleştirildiğini söylemek mümkündür. TV programlarında bedenler modifiye edilerek sergilenir ve simülakr özne bu kısımda inşa edilir. Bu süreçte bireyler kendi bedenlerini ideal beden algıları çerçevesinde değiştirmeye ve inşa etmeye başlarlar. Yani bedenin inşası, olması gerektiği düşünülen ideal beden algısı üzerinden gerçekleştirilmektedir. Burada kastettiğimiz inşa aslında sadece bedeninin inşası olmayıp aynı zamanda bireylerin toplumsal hayattaki kişilik ve kimliklerinin de bir inşasıdır. Bu sürecin dikkat çekici yönüne Kızılçelik (2003: 90) "bedende arızalı olan parçası değiştirilerek, ötekinin erotik bakışına sunulan ve maddi değeri olan bir nesneye dönüştürülmüss, neredeyse bireyin sermayesi haline gelmişliğiyle” vurgu yapmaktadır. Yaktıl Oğuz, (2005: 32) ideal beden söylemine maruz kalan ama bu beden görünümüne ulaşamayan kadınların kendi görüntüleri kendilerini mutsuz hissetmelerine neden olur yani beden imgeleri olumsuz şekillerde oluştuğundan bahsetmektedir. Ortaya çıkan bu olumsuz beden imgesinin ise bireylerin yaşamında bazı problemlere, depresyonlara ve gereksiz plastik cerrahiye neden olduğunu söylemektedir. Bu görüşü destekler nitelikte Byung-Chul Han "sergi değeri her şeyden önce güzel görünüşe bağlldır" demektedir. Sergi değer aynı zamanda "günümüzdeki güzellik olgusunun kusursuzlukla eşdeğer anlaşılmasına neden olmuştur” (Bilgin, 2016: 234). Kusursuz güzellik ise kusursuz yani mükemmel beden algısı ile oluşmaktadır. Öyle ki günümüz imaj kültüründe doğal bir son olan yaşl1lık dahi bir sorun olarak algılanmakta ve çoğunlukla yapay yollarla engellenmeye çalışılmaktadır. Çünkü yaşlı beden bireyleri kusursuz beden görünümlerinden uzaklaştırmaktadır. $\mathrm{Bu}$ nedenle "yaşlı bireylerin dahi genç kalmak için spor salonlarına gittiği toplumlarda yaşlılık istenilmeyen, geciktirilmesi gereken bir dönem olarak değerlendirilmektedir" (Canatan, 2015: 327).

Güzellik söyleminin yaygınlaştırılmasında ve bireylere aktarılmasında medya gibi televizyon programları da etkili araçların başında gelmektedir. Bu bağlamda çalışmada da "Bu Ben Miyim" adlı bir televizyon programı örneklem olarak seçilmiştir. Çünkü "televizyon programlarında güzellik söylemi aracılığıyla ideal ve ulaşılması imkânsız olan gerçek üstü bir beden imaj1 sunulmakta ve daha sonra bu programlarda kadın bireylere gizlemeleri gereken bedensel kusurları sert bir şekilde gösterilmektedir" (Özgen, 2017). Bu söylemlerin televizyon gibi etkili bir kitle iletişim aracından aktarılması bireyler tarafından çok daha fazla benimsenmesine neden olmaktadır. Çünkü televizyon "sosyokültürel ideallerin en güçlü aktarıcılarından biri olmasından dolayı toplumda önemli bir role sahiptir." (Yaktıl Oğuz,2005:31). Bu noktada artık kimliklerin inşa edilebilir gerçeklikler olduğu söylenebilir. Bauman'a göre kimlik inşası durdurulması olanaksız bir deney haline gelmiştir. Bir denemede tek kimlik denenir ama denenmemiş olan birçok kimlik vardır. Yaşamımız boyunca kurgusu dahi yapılmamış birçok kimlik inşa edilmeyi beklemektedir. Mevcut olan kimliğin en yüksek tatmini oluşturabileceğini veya ulaşabileceğimiz en iyi kimlik olduğunu asla tam anlamıyla bilemeyiz (Bauman, 2019: 104). Bu nedenle de kimlikler sürekli bir inşa halindedir. $\mathrm{Bu}$ çalışmada beden imajları, ideal beden ve güzellik söylemleri değil simülakr bir özne olarak bedenin inşasının nasıl gerçekleştirildiği ele alınmıştır. Ayrıca çalışmanın odağına yerleştirilen kavramsal olgu "kadın bedeni”" olmuştur. Araştırmanın amacı doğrultusunda "Bu Ben Miyim (Doktor B)" programı içerik ve söylem analizi yöntemiyle "damgalama", "kusursuz beden algisı", "duyguların yönetimi", "sergileme ve gizleme değeri" gibi dört kategori altında incelenmiştir. Kategoriler, araştırmanın odak noktasının bedeni tanımlarken onu kültürel ve sosyal bir inşa olarak kabul edildiğinin bağlamından hareketle üretilmiştir. Hazırlanmış olan bu çalışmada bedene müdahale, kişinin bedeniyle ilişkili tutumlarının oluşması sonrasında estetik ameliyatlara başvurmasıyla sonuçlanmaktadır. Katılımcıların ameliyatlarla ilgili talepleri hem toplumsal etkileşimlerin sonucunda ortaya çıkmakta hem de bireylerin bedenleriyle ilgili kişisel tutumlarının sonucudur. Byung-Chul Han'a göre ise günümüzde beden estetik ya da sağllk bağlamındaki 
optimizasyonun ilgi alanındadır. Bu nedenle bedene yönelik ortopedik müdahale kendi yerini estetik müdahaleye bırakmaktadır. Yani "disipline edici ortopedinin yerini estetik cerrahi ve spor salonları almaktadir.” (Byung-Chul Han, 2019: 33).

\section{Araştırmanın Metodolojisi ve Veri Analiz Stratejisi}

Doktor B'nin sosyolojinin konusu haline getirilmesi, kişinin estetik için bu ameliyatların yapıldığı mekâna adım atıyor oluşunun kaynağında toplulukla kurduğu ilişkinin bir sonucu olmasıdır. Mekân bu anlamıyla toplumsal içerikleriyle gündeme gelmekte ve üretilmektedir. Mekân bu bağlamıly bir çeşit disiplin ve kontrol merkezine dönüşmektedir. Beden toplumsal yüklemelerin merkezi olarak tanımlanmaktadır. Fiziksel olarak kaş eşitsizliği, kepçe kulak, göğüs küçüklüğü veya eşitsizliği, kanser sonrası gögüs eksikliği bütün bunların ortak bağlamı ortak birleştikleri nokta toplumsal anlamda değer yüklü olmalarıdır. Toplumsal kabullerle üretilen bedenin mekâna girişi aynı zamanda hikâyenin de başlangıç noktasıdır. "Toplum onu nasıl görecektir? ” sorusuna verilecek yanıt yine topluma açık bir program üzerinden aranmaktadır. Çünkü birey aynanın karşısına geçtiğinde salt kendisiyle muhatap olmak dışında kendisini toplumsal alana hazırlamaktadır. Aynadan "sen "leri görerek toplumla bütünleşme yaşamaktadır. Aynada yaşadığı bütünleşme özneyi anonimleştirmektedir. Anonimleşme, herkes gibi ideal bedene sahiplik, herkes gibi güzel olma, kadın gibi kadın erkek gibi erkek olma sürecidir. Ancak bütünsel olarak bakıldığında bedene toplumsal çıkarımlarla yüklenen anlamlar söz konusudur. Bu nedenle çalışmaya konu olması bakımından Doktor B'ye gelen katılımcılar toplumun baskısı altındadır. Katılımcılar, dinin bedene müdahaleyi hoş görmemesi gibi (Eliade, 1991) güçlü kabulleri paranteze alır. Din gibi bedene müdahaleyi sınırlayan kutsalların paranteze alınması, beden bozukluğu söylemiyle birey üzerine kurulan kolektif baskının güçlü oluşunu gösterir. Bireylerin değişim taleplerinde anonimlik ağır basmaktadır. Böylece topluma tam erkek ya da tam kadın gözükmek istenmesi, eksikliklerden kurtulmak ve toplumsal kabulü sağlamak anlamına gelmektedir. Burada çalışmanın en başına dönüşü temsil etmesi bakımından simulakr öznenin en güçlü taraflarından birisinin anonimlik olduğuna vurgu yapmak gerekir. Yani fotoğraf çektikten sonra bedene müdahale etmek için komut bekleyen uygulamalar, kişinin telefon ekranına bakarken aynaya bakarken takındığı tavırla benzer içeriğe sahiptir. Böylece gösteri dünyasının idealize ettiği biçime bürünmek hem ayna karşısında hem de telefon ekranında sağlanmaktadır. Bu anonimlik yerini, üzerinde oynanan görselleri sosyal medyaya yükledikten sonra herkesin birbirine benzemeye başladığı görüntü sarmalına bırakmaktadır. Bu aynı zamanda bir escher evrenidir ve diyalektik bir paradoksu içermektedir. Sağır ve Aktaş (2019) çalışmalarında dile getirdikleri gibi escher evreni tanımlayan yegâne şey yeniden üretim sürecidir. Bu üretim sürecinin farkında olmadan yapılmasıdır. Arkasından bilinçli bir şekilde üretimin devam etmesidir. Akçay (2004: 234) gündelik hayatın bedenlerin üretimi ve yeniden üretiminden başka bir şey olmadığına yaptığı vurguyla aynı bağlamı güçlendirmektedir. Yani gündelik hayatta bireyin kimliklerinden önce bedenlerinin üretilmesi gelmektedir.

Artık sosyal medyadaki görüntülerin hiçbirisi doğal değildir. Tıpkı güzellik endüstrisindeki müdahalelerin bedenin doğallığını bozması gibi sonuçları benzerdir. Bu bağlamdan hareketle çalışmanın örneklemi "Bu Ben Miyim?” isimli televizyon programıdır. Programın en temel özelliği, bir estetik cerrahi merkezinde gerçekleşen ameliyatları "katılımcıların hayat hikayeleriyle bütünleştirerek" sunuşudur. Ayrıca programın katılımcıları, kendi istekleri çerçevesinde bedenlerine estetik müdahaleler yaptırmakta ve yayın süresince bu müdahalenin meşruluğu, hayat hikayeleriyle birleştirilmektedir. Araştırma doğrultusunda incelenen bu televizyon programı katılımcıların günlük hayatlarında bedenlerindeki gizlemek istedikleri kısımları ideal görünüşler çerçevesinde inşa ederek bireylere ve izleyici kitleye sunmaktadır. Bu inşa sonucunda katılımcılar estetik müdahale öncesindeki gizlenme duygusundan çıkarak yenilenmiş vücutlarını sergileme duygusuna geçmektedirler. Fakat Byung-Chul Han'ın da belirtmiş olduğu gibi "sergilenme, teşhir edilme mecburiyeti bizzat bedenin yabancılaşmasına yal açmaktadır" (Byung-Chul Han, 2017: 28). 
Araştırmanın amacı doğrultusunda içerik analizi yöntemi kullanılmıştır. İçerik analizi yöntemi ile araştırma bağlamında yazılı, sözel veya diğer verilerin nesnel şekillerde incelenerek bu verilerin içerisindeki saklı olan gerçeklikleri görünür k1lmak ve açıklamak amaçlanmaktadır (Gülbahar ve Alper, 2009: 100). Krippendorf'e göre (2018: 18) içerik analizi metinlere ve kullanıldıkları bağlamlara yönelik anlamlı ve geçerli sonuçlar çıkartabilmek için kullanılan bir araştırma tekniğidir. Krippendorf içerik analizinde altı soruya yanıt arandığına vurgu yapmaktadır (Kaya ve Usluel, 2011: 50). Bunlardan ilki hangi verilerin analizi yapılacağıdır. Diğerleri ise sırasıyla "verilerin nasıl tanımlamış olduğu", "verilerin analizinin yapılacağ bağlamın ne olduğu", "analizin sinırları", "çıkarsamaların hedefi" ve "verilerin toplandiğı grubun ne olduğu” "dur. İçerik analizinin amacı metin ya da görsel özellikler aracılığıyla bir olgu ya da topluluğun nasıl yansıtıldığını açıklamaktır (Bell, 2001). Bell'in içerik analizinden hareketle çalışmaya konu olan programda kategoriler belirlendi ve program bir metin kabul edilerek kategoriler çerçevesinde analize tabi tutuldu. Bilgin'e göre (1999) tüm iletişim ortamları göstergelerle inşa edilen bir alan olmakla birlikte, deşifre edilmeyi, kod çözümünü, yorum ve çıkarsamayı gerektiren söylemsel metinlerdir. Böylece kategorilerin oluşturulması, programın parçalara ayrılarak çok sayıda veri ağını parçalara ayırmayı hedeflemektedir (Bell, 2001: 16). İçerik analizinde sadece görünen içeriğin incelenmesi veri analizi için yeterli değildir. Bu analiz tekniği aynı zamanda incelenen malzemenin arka planını da inceleme konusu yapmakta, metnin tema ve içeriğini temel analiz biçimi olarak değerlendirirken, bağlam dokusunu da alt okuma olarak analize katmaktadır (Mayring, 2009: 2). Bu doğrultuda araştırmada ele alınan "Bu Ben Miyim?" programı incelenirken "damgalama", "kusursuz beden algisl", "duyguların yönetimi", "sergileme ve gizlenme değeri" şeklinde belirlenen dört ana kategori kullanılmıştır. Bu analiz sürecinde programa katılan katılımcıların medeni durumları, yaşları, kaç defa ameliyat oldukları gibi özellikler de göz önünde bulundurulmuştur. Aynı zamanda programın gerçekleştirildiği mekân ve mekânın organize ediliş biçimi (renk, ses, katılımcılara giydirilen kıyafetler, muayene ve ameliyat ortamı vb.) analize tabi tutulmuştur.

Araştırmanın evreni "Bu Ben Miyim? (Doktor B)" adlı TV programının araştırma sürecinde yayınlanın tüm bölümlerini içermektedir. Program 2 sezon ve toplam 16 bölümden oluşmaktadır. $\mathrm{Bu}$ bölümlerle araştırmada doygunluk noktasına ulaşıldığı düşünülmektedir. Programa araştırma sürecinde toplam 45 birey katılmıştır ve bu bireylerin 34'ünü kadınlar 11'ini ise erkeklerden oluşmaktadır. Programın yayınlanmış bölümlerinin toplam süresi 764,52 dakika (12 saat 40 dakika) dır. Programın genel akışı ilk olarak katılımcıların kendilerini tanıtmaları, bedenlerindeki rahatsız oldukları problemleri belirtmeleri bu problem nedeniyle ne gibi zorluklar yaşadıklarını dile getirmeleri ve katılımcı yakınlarının katılımcının rahatsız olduğu vücut bölümleriyle ilgili görüşlerini belirtmeleri ile başlamaktadır. Daha sonrasında katılımcılar ilgili doktor (Doktor B) ile tanışmakta ve bedenlerindeki rahatsı oldukları kısımları anlatmaktadırlar. Katılımcıların istekleri doğrultusunda Doktor B, katılımcıların bedenlerindeki rahatsız oldukları kısımları incelemekte ve beğenilmeyen beden görüntüsünün yeniden inşa edilme sürecinin genel çerçevesini oluşturmaktadır. Sonrasında ise katılımcıların bedenlerine cerrahi müdahaleler başlamakta, ameliyat anının, ameliyattan hemen sonrasının ve bir-iki günlük müşahede sürecinin görselleri yansıtılmakta ve bu süreçlere izleyiciler de dâhil edilmektedir. Programın son kısımlarında ise ameliyat olan bireylerin ameliyattan ne kadar memnun olduklarını dile getirmeleri ve yeni beden görünümleri ile hayatlarında ne gibi değişimlerin olduğunu belirtmeleri için kamera bireylerin sosyal yaşam alanlarına çevrilmektedir. Bu kısımda özellikle bireylerin daha önceden rahatsız ameliyat sonrasında ise aşırı memnun oldukları vücut kısımları ön plana çıkarılmakta ve izleyicilere sergilenmektedir. $\mathrm{Bu}$ bağlamda araştırmada programın bir bölümünün üç aşamada incelenmesi düşünülmüştür. Birinci aşama programın en başında katılımcıların kendisini tanıttığı ve bedenlerinde istenmeyen parçaların gösterildiği temalarından oluşmaktadır. Buraya ameliyat olacak kişilerin yakınlarının, kişinin bedeniyle ilgili görüşlerinin verildiği bir kısım eşlik etmektedir. Diğer bir aşama ise ameliyat sonrası kişinin neye benzeyeceğinin tasarlandığı bilgisayar simülasyonlarının kullanıldığ 1 görüntülerden 
oluşmaktadır. Son aşama ise kişilerin ameliyat sonrası yeni bedenleriyle günlük yaşama dönüşlerini ve o kısımdaki davranışlarını içermektedir.

Bu çalışmada ayrıca Doktor B örneği ile simulakr öznenin gerçek hayattaki karşıllkları araştırılmaktadır. Aynı zamanda çalışma, sosyal medyada özne inşasıyla güzellik endüstrisindeki inşanın benzer ortaklıklardan hareket ettiğini göstermek için hazırlanmıştır. Bu bağlamda gerçek hayatta simulakr özenin ve sosyal medyada öznenin inşası arasındaki ortaklık da vurgulanmıştır. Katılımcıların kendilerinden niçin uzaklaştıklarına dair alt okumalar yapılmıştır. Araştırmada, idealize beden algısının incelenmesi, toplumsal kabullerin beden üzerindeki güçlü yanlarını temsil etmesi bakımından toplumsal cinsiyet, son olarak ise bedene mühalede etmenin ciddi sağ lık sorunları yaratacak olma ihtimallerine rağmen kişilerinin istekli olmaları önemli kriterler olarak görülmüştür. Dolayısıyla bu bağlam çalışmanın ulaşacak olduğu nihai nokta açısından önemsenmiştir.

Tablo 1: Program Katılımcılarının Demografik Yapıs1

\begin{tabular}{cccc} 
& Değișkenler & Frekans & Kadın \\
\hline \multirow{3}{*}{ Cinsiyet } & Kadin & 34 & 75,6 \\
& Erkek & 11 & 24,4 \\
\cline { 2 - 4 } & Toplam & 45 & 100 \\
\hline \multirow{4}{*}{ Yaș } & 19 ve altı & 4 & 8,8 \\
& $20-30$ & 16 & 35,5 \\
& $31-41$ & 15 & 33,3 \\
& $42-52$ & 8 & 18 \\
\cline { 2 - 4 } & $53-63$ & 2 & 4,4 \\
\hline Medeni & Toplam & 45 & 100 \\
Durum & Evli & 18 & 40 \\
& Bekar & 27 & 60 \\
\cline { 2 - 4 } Meslek & Toplam & 45 & 100 \\
& Öğrenci & 7 & 15,5 \\
& Ev Hanımı & 13 & 28,9 \\
& Memur & 1 & 2,2 \\
& İşçi & 3 & 6,6 \\
& Diğer & 21 & 46,8 \\
\hline & Toplam & 45 & 100 \\
\hline
\end{tabular}

Yukarıda verilen tabloda da görüldüğ ü üzere programa katılan bireylerin \%75,6'sı kadın $\% 24,4$ 'ü ise erkeklerden oluşmaktadır. Bu veri kadınların erkeklere oranla daha fazla katılım gösterdikleri şeklinde yorumlanabilir. Programa katılım gösteren bireylerin \%35,5'i 20 ila 30 yaş aralığında, \%33,3'ü ise 31 ila 41 yaș aralığındadır. Yani programa katılım gösteren bireylerin çoğunluğu genç ve orta yaşlı insanlardır. Bu durumda genç bireylerin diğer yaş guruplarından daha fazla kendi beden görünümlerinden tatmin olmadıkları ve bedenlerinde bazı değişiklikler yaptırmak istedikleri söylenebilir. Özellikle erkek katılımcıların neredeyse tamamının gençlerden oluşması, kadınların her yaştan estetik ameliyat için başvurmaları dikkat çekici bulunmuştur. Tablo incelendiğinde katılımcıların \%60'ı bekarken \%40'1 evli bireylerden oluşmaktadır. Özellikle programa katılan erkeklerden iki kişi hariç hepsi bekar bireylerden oluşmaktadır. Elde edilen bu verilere göre programda öncelikle bekar insanların daha fazla estetik yaptırtma tercihinde bulundukları teması belirmektedir. Tabloda katılımcıların mesleklerine bakıldığında ev hanımlarının programa katılanların \%28,9'unu, diğer seçeneğinde bulunanların ise katılımcıların \%46,8'ini oluşturdukları görülmektedir. Diğer grubunda bulunan mesleklerden bazıları kuaför, güzellik uzmanı, makyaj uzmanı, estetisyen gibi beden ve güzellik ile doğrudan ilişkili olan mesleklerken; bazıları da yönetici, yönetici asistan, müşteri temsilcisi meslekleridir. Bu mesleklerin bir alt görünümü kuşkusuz insanlarla sürekli bedenle kurulan bir iletişim halinde olmayı gerektirmesidir. 


\section{İdeal Beden Görüntüsüne Yüklenilen Anlamlar}

“Bu Ben Miyim? (Doktor B) ” programına katılan bireylerin ideal beden görünümüne dönük söylemleri; kusursuz beden tanımlaması, bu beden görünümüne ulaşmak amacıyla bedene/sağlığa zarar verilmesi ve beden üzerinden toplumsal cinsiyet rollerine atıf yapılması altbaşlıklarıyla değerlendirilmiştir. Programda kullanılan söylemlerin bütününe bakıldığında ideal beden algısının tek tip olmayıp, her bir katılımcının kendileri için oluşturdukları farklı bir ideal beden algısı bulunduğu görülmüştür. Programa katılan bireylerin zihinlerinde oluşan ideal beden algısı genellikle kendi bedenlerinde beğenmedikleri ya da eksik gördükleri kısımlar üzerinden tanımlanmaktadır. Programdaki bireylerin ideal beden görünümü hakkındaki söylemlerinde şu noktalara dikkat çekildiği görülmektedir.

Keşke diyorum benim de gözlerim eşit olsa kalem çekebilsem bütün kızları görüyorum, ergenlik döneminde herkes çekiyor ama ben çektiğimde yani yamuk oluyor biri büyük biri küçük oluyor ve iki gözümde aynı olmadığı için beni çok mutsuz ediyor (Ç.Ö/ 16:2016:34).

Yani hayal ettiğim bir kilodayım, istediğim bir kilodayım, hedeflediğim bir kilodayım ama hayal ettiğim bir vücutta değilim. 40 beden bile olsam yeter ki düzgün bir fiziğim olmasinı tercih ederdim yani (Y.C/ 11:04-11:16).

$\mathrm{Bu}$ hayattaki en büyük tutkum ağırlık kaldırmak, vücut geliştirme sporu. Bu spora başlamamın en büyük etkeni zayıf ve çelimsiz olmamdı. Daha sonra birkaç arkadaşım da benim gibi onlar da zayıftı vücut geliştirmeye başlamışlardı spor salonuna yazıldılar ben de bir denemek istedim belki spor yaparak kilo alırım biraz hacimlenirim, vücudumda bir değişiklikler olur böyle düşündüm ve ben de gittim spor salonuna kayıt oldum (S.Ö/ 15:52-16:24).

Yukarıdaki örneklerde de görüldüğü üzere bireylerin açık veya dolaylı bir şekilde tanımladıkları ideal beden algıları, kendi bedenleri üzerindeki beğenmedikleri kısımların eleştirisi ve yeniden biçimlendirilmesi talebi üzerinden oluşmaktadır. Katılımcılar ameliyat öncesinde bilgisayar programı aracılığıyla ameliyat sonrasında neye dönüşeceklerinin simülasyonunu seyretmektedirler. Böylece simulakr özne, ameliyat sonrası nasıl bir bedene sahip olacağını teknik olarak bilgisayar üzerinden görmekte ve olası değişimini onaylamaktadır. İdela bedenle ilgili öznenin sahip olduğu tutum, ameliyat öncesinde teknik bilgi aracılı̆̆ıyla onaylanmaktadır. Özne soyut olan tasarımı, somut olarak bilgisayarda görebilmekte ve ameliyat süreci bu şekilde başlamaktadır. Aşağıdaki söylemde de bu durum açık bir şekilde görülmektedir;

Bilgisayarda gördüğüm görüntü çok mutlu etti ona yakın bile olsa çok daha mutlu olacağım. Yani deforme olmamış, daha genç, daha sıkı, daha yakışıklı baya bir şaşırdım, çok hoşuma gitti yaklaşsam bile bana yeter o (M.Y/ 23:25-23:43).

Katılımcıların ideal beden görünümüne yüklediği anlamlar, kendi sorunları üzerinden gerçekleşmektedir. Bu bağlamada ameliyata yüklenen anlam gündelik hayata yeni bir kimlikle sıfırdan başlamaktır.

Karnımı ameliyat sonrası gördüm, beğendim ama en önemlisi olan tamamen ameliyatın yerine oturup bir 3-4 ay sonraki son halini görmeyi çok merak ediyorum. Hani bir ince belim olacak, düzgün bir kıvrımım olacak. Ben de her kadın gibi güzel bir elbise giyebileceğim, güzel bir etek giyebileceğim (D.G/ 45:09- 45:33).

15 yıldır en büyük hayalimdi şu kaşlarımın birbirine eşit olması ve şuan ikisi aynı yani yerde gözüküyor, simetrik bir yüzüm var, göz kapaklarım düzelmiş şekilde duruyor (G.K/ 34:50-35:05).

Yüzümü gördüm aynada şaşırdım sanki ben değilmişim gibi geldi bana daha güzel bir yüzüm var sanki daha orantılı. Artık incecik bir belim var dümdüz bir karnım var. Yüzümde çok güzel oldu (A.Ç/ 32:42- 33:29). 
Programa ameliyat olmak için katılan bazı katılımcılarda toplum tarafından oluşturulan ideal beden algısından kaynaklı kusursuz bir beden görünümüne sahip olma kaygısı ve bu beden ile onaylanma isteği vardır. Bu önermeyi güçlendiren en temel örnek aşağıda belirtilmiştir:

Askerden geldikten sonra fit bir vücuda sahip olabilmek için kilo vermeye karar verdim. Sağlıklı yaşam biçimine büründüm, spor yaptım iki yıl boyunca o sarkmalardan dolayı bu beni hiç mutlu etmedi. Orana ne oldu yani direk karşıdan gelen tepki bu hiç kimse güzel vücudu görmüyor direk o deri sarkıntısını görüyor ve o da benim çok moralimi bozuyor (Y.E.Ç/ 14:11- 15:18).

Görüldüğü üzere katılımcılarda ideal beden algısından kaynaklı fit bir vücuda sahip olma isteği vardır. İstenilen fit görüntüye ulaşılsa da ikinci aşamada bedenin kusursuzluğunu bozan yeni sorunlarla baş edilir. Örneğin bedenin ayna karşısında görüntüsünü bozan deri sarkıklığı rahatsızlık vermeye başlar. Çünkü deri sarkıklığı ideal beden tanımını bozmaktadır. Bu şekilde sürecin bir paradoksa dönüş̧üğü görülmektedir. Hiç bitmeyecek ameliyatların öznenin bedenini sürekli inşa etmesi olasıdır. İdeal beden kaygısı taşıyan birçok kişi ise ideal beden görünümüne ulaşmak için sağlıklarına bilinçli ya da bilinçsiz bir şekilde zarar vermektedirler. Aslında yapılan estetik ameliyatlar sağlıkla ilgili yeni problemleri ortaya çıkartmakla birlikte estetik kaygıyı daha yoğun taşıdığı görülmektedir. Örneğin programda doktor ve hasta arasında geçen aşağıdaki diyalog bu konuda önemli örnektir.

D.B: Şimdi en başa dönsen sarkmışsın ya bir de bir sürü tehlikeler atlatmışsın yine mide küçültme ameliyatı olur muydun?

N.K: Ölümden döndüm, ölüyordum zayıflamak için ama yine aynı cesareti gösterir olurdum ki şuanda da onun için buradayım. Yani yine olurdum.

D.B: Zayıfladın daha kendini iyi mi hissediyorsun?

N.K: Çok daha iyi hissediyorum. Çok zor günler yaşadım evet çok meşakkatli bir dönemdi ama onlar bittiğinde her şey geçtiğinde çok iyi hissediyorum kendimi (N.K/ 5:08- 5:45).

Yukarıdaki diyalogda da görüldügü gibi bireyler istedikleri beden görünümüne ulaşabilmek için sağlıklarıyla ilgili büyük risk alabilmektedirler. Aşağıda verilen örnekler de bu görüşü destekler niteliktedir.

İnsan var olan bedeniyle ilgili kalıcı bir rahatsızlığa sahip olmayı düşünebilir mi zayıflık uğruna? Maalesef ben bunu yaptım. Karşıma çıkan ilk madde ye ve kus oldu ve bunu yaptım. Hatta gizlice yaptım. Çoğu zaman kontrolsüzce yaptım. Uzun açlık saatleri sonrasında yedim istemsiz ve kontrolsüzce yedim, çok yedim ve sonra kustum (23:5924:30). Bu yeme ve kusma yani ödüllendirme ve cezalandırma bir $4-5$ ay kadar sürdü. İlk etkilerini gördüğümde çok heyecanlanmıştım çok güzeldi. İlk ay 12-13 kiloya yakın kilo verdim bu mükemmel bir şeydi. Sonra detokslar başladı sadece sıvıyla beslenmek. Sonra biraz daha abartıp açlık nöbetleriyle daha ağır ve daha yoğun sporlar yapmak. Ama inanın sonu hep hastanede bitiyor. Çünkü daha düşük bir nabız daha düşük bir tansiyon ve daha düşük bir bağışıklık sistemiyle herhalde bu şekilde devam etseydim bir yıl içerisinde ölürdüm (A.T/ 24.37- 25:11).

M.Ö: Ve kendi araştırmalarında anabolizan ilaçlar gibi böyle maddeler varmış hocam bunlar çok kilo aldırıyor ve kas kütlesini daha çok artırdığını söyledi. Ben de ona kesinlikle bunları kullanmayacağını ve vücudunda ciddi handikaplar ve zararlar vereceğini söyledim.

S.Ö: Tabi ben ona vazgeçmiş hissi verdim ama düşündüğümde zararlarını hiç umursamadım. Bir takım takviyeler kullanmaya başladım steroid dediğimiz doping maddeleri, karbonhidrat tozları olsun, haplar olsun, protein tozları olsun o noktaya geldiğinizde vücudunuza vereceğiniz zararı hiç düşünmüyorsunuz (S.Ö/ 15:52- 17:20). 
Bu çaresizlikten o kadar yoruldum ve bıktım ki çeşitli çeşitli şeyler düşünmeye başladım ondan kurtulmak için (göbeğini kastediyor) kafamda bir sürü deli şeyler planlamaya başladım. Gerekirse dedim keseyim atayım ben kendim onu yok edeyim (E.A / 3:29$3: 43)$.

Son olarak belirtilmesi gereken husus beden üzerinden toplumsal cinsiyet rollerinin yeniden üretildiği ve bu şekilde sürekli hale getirildiğidir. Herkesin zihninde bilinçli olarak ya da farkında olmayarak erkek ve kadın beden görünümüne dair bir tanımlama bulunmaktadır. Programa katılan erkeklerden birçoğu görünümlerinin kadın bedenine benzediğinden şikâyetçi olurken aynı şekilde birçok kadın da görünümlerinin erkek bedenine benzemesinden rahatsızdır. Erkek ve kadın bedeninin nasıl olacağına dair özellikler toplum tarafından önceden belirlenmiş ve kategorileştirilmiştir. Toplumda var olan beden kalıplarına uymayan bireyler, ideal kadın veya erkek görünümüne uymadığı için ameliyat talep etmektedirler. Programa katılan bireylerin söylemleri incelendiğinde bu görüşü destekler nitelikte birçok veri elde edilmiştir. Örneğin:

Bir erkek olarak bir kadın göğsüne sahip olmak onun için büyük sıkıntı. Bir erkeğin vücudunun bir erkek gibi gözükmesi, en azından bir ortalama erkek kadar güzel gözükmesi onun içinde önemli (A.U/ 15:27- 15:36).

Aynaya baktığım zaman bir erkek vücudundan daha çok aslında kadınsı bir vücut görüyorum. Yani kıvrımlı yumuşak bir vücuttansa kendi sahip olamam gereken asıl vücuduma sahip olmak istiyorum daha keskin hatları olan. 23 yaşında bir erkeğin olması gerektiği gibi vücuda sahip olmak istiyorum (O.C/ 9:33- 10:05).

Gerçekten hani rahatladığımı, ilk baktığım anda görünüşünün hani o kadınsı görünüşten kurtulduğumu hissettim, gördüm (S.Ö/ 26:58- 27:06).

Çok güzel olmuş çokta beğendim. Aynadan kendime baktığımda artık tüm vücudumla bir kadın olarak kendimi görüyorum ve hissediyorum. Eskiden kafamdan aşağı baktığımda bir erkek vücudu görüyordum ama şimdi bir kadın vücudu görüyorum (Ö.D/ 37:0037:15).

Yani bende kadın oldum yani tamamen kadın oldum. (27.41- 27:44) Artık kendimi bir çocuk değil de hani çocuk bedeni değil de kadın bedenini taşıyormuş gibi hissediyorum şu an ve evime koşmak istiyorum (D.K/ 40:40- 40:47).

Yukarıda da belirtilmiş olduğu gibi erkekler beden görünümlerinin kadına benzemesinden, kadınlar ise beden görünümlerinin erkeğe benzemesinden son derece rahatsız olmaktadırlar. Aynı şekilde kadınlar bedenlerinin bir çocuk bedeni gibi görünmesinden de rahatsız olmaktadırlar. Çünkü kadın olmak için tüketim ve moda endüstrisi içerisinde kabullenilmiş olan ideal kadın görünümüne sahip olmak gündelik hayatı sürdürebilmek için zorunluluk olarak düşünülmektedir (Yaktıl-Oğuz, 2005; Doğan, 2010). Yani sadece cinsiyet olarak kadın olmak yeterli değil aynı zamanda fiziksel olarak bel kıvrımına, kalça kıvrımına da sahip olmak gerekmektedir. Programa katılan hem kadın hem de erkek bireylerin söylemlerinden de bu düşünceye sahip oldukları anlaşılmaktadır:

Operasyon sonrası aynada ilk kendimi gördüğümde kadın gibi hissettim çünkü bel kıvrımım var, kalça kıvrımlarım var (Y.Ö/ 43:13- 43:30).

Kadın dediğinizde kıvrımlı, bakımlı, balık etli, güzel ve çekici olmasını herkes bütün erkekler ister. Tabi bütün erkekler gibi fiziği olmasını ben de isterim (Ö.D/ 8:49- 9:03).

Ben kendime baktığımda da güzel görünmek isterim yani eşimin yanında işte sosyal çevremde yani her zaman güzel olmak isterim. İki göğsüm birbirinden çok farklı biri yukarıda biri aşağıda uçları farklı her yeri dikiş, kesik (S.A/ 3:12- 4:53).

Beden üzerinden kadınların yaşadıkları bir diğer sorunsal da kendilerini yetersiz yani eksik hissetmeleridir. Bu eksik hissetmenin temel nedeni de kendi bedenlerini ideal olarak belirlenmiş beden kalıplarından uzak görmeleridir. Dolayısıyla kadınların hem eşlerine hem de çocuklarına karşı 
kendilerini kötü hissettiklerini belirtmek mümkündür. Bu kaygı sonucunda kendilerinin "tam olarak anne" veya "tam olarak eş" kavramlarını dolduramadıklarını düşündükleri görülmektedir.

Eşimle de sıkıntılar yaşadım artık hani vücudun niye böyle neden böyle kendime artık sıkıntı yapıyorum hani özel hayatımız bile artık çığırdan çıktı hani. Sonra çocuklarım oldu çocuklarımı emziremedim çünkü yok göğüs yok (1:38- 1:53). Ben veremedim iki çocuğuma da veremedim o sütü yani ben tam olarak anne olamadım hani o anneliği yaşayamadım ben. Eşime de aynı şekilde tam olarak hani eş olamadım kendimi öyle hissediyorum (D.K/ 3:30-3:45).

Kendimi her zaman eksik buluyorum bu konuda ve kendimi tam olarak bir kadın gibi hissedemiyorum dışarıda mesela yani yürüdüğümde insanların daha çok benim göğüslerime baktığını düşünüyorum çünkü çok küçükler. Eşim tarafından da beğenilmediğimi düşünüyorum (8:36-8:48). Ben hissediyordum sevmediğini bu şekilde beğenmediğini ben hissediyordum. Ya da bana hissettiriyordu (Ö.D/ 9:4- 9:10).

\section{Beden Üzerinden Kimlik İnşası}

Beden üzerinde gerçekleştirlen operasyonlar aynı zamanda bir kimlik inşa sürecini de beraberinde getirmektedir. Özellikle bazı söylemler incelendiğinde bedenin istekler doğrultusunda yeniden oluşturulduğu dikkat çekmektedir. Örneğin;

Doktor B: (Muane ederken): Ne kadar büyük olsun? Doğumlara bağlı biraz derisi de bozulmuş onları da düzelteyim, biraz gençleştirme yapayım aynı zamanda. Göbek deliğini de doğum yapmamış gibi yapayım mı? Genç kız olacaksın yeniden ister misin? Hem karnını hem göğüslerini genç kız göğüsleri gibi yapacağım. Sezaryen izin de kötü düzelteyim mi bunu da? (D.K/ 4:22- 6:11).

Annesi: Ben onları çok güzel çocuklar olarak yetiştirdim, doğurdum çok şükür beyinleri akılları çok güzel ama vücutlarını güzel demek ki yaratamadım. Hocam onu da size emanet edeceğim arttık (E.Ö/ 8:32- 8:44).

Doktor B: Yüzünde doğal fark edilmeyen ama çekici bir gençleşme olur. Ama burnun doğal bir şekilde değiştirilemez. Birazda dudaklarını gençleştireyim (Y.M/ 10:38- 11:18).

Doktor B: (Boyun kısmına küçük bir müdahale yapılıyor) Bu bile seni çok değiştirecek yani şu yaptığım küçücük bir müdahale bile çok değiştirecek. Boynun kuğu boynu gibi olacak hem de çenen biraz yukarı doğru kalkacak ve dik duracaksın dik her zaman dik. Gözün yukarılarda olsun Dilnoza (D.G/ 31:28- 31:44).

Bu örneklerde de görüldüğü gibi uzman doktor aracıllğıyla beden görünümleri katılımcının talebi doğrultusunda yeniden oluşturulmaktadır. İnşa edilen bu bedenlerin insanların hayatlarını her bakımdan olumlu yönde etkileyeceğine dair de katılımcılarda kesin bir inanç bulunmaktadır. Örneğin;

Doktor B: Ona yapacağım küçük bir dokunuşun hayatını çok olumlu etkileyeceğini düşünüyorum (B.Ç/ 11:32- 11:44).

Vücudumda rahatsız olduğum bölgeden kurtuldum tartıda bir buçuk kilo falan çıkıyor ama benim için çok büyük bir şey istediğim şekilde sosyal yaşamımda beni çok güzel etkileyeceğini düşünüyorum. Şu an çok mutluyum (Y.C/ 44:54- 45:09).

Yapılan müdahalelerin insanların hayatlarını olumlu yönde etkileyeceği düşüncesinin yanısıra katılımcıların programda sıklıkla "yeni hayat, yeniden doğmak ve yenilenmek" kavramlarını kullandıkları görülmektedir. Bu durum aslında beden üzerinde yapılan değişikliklerin katılımcıların gündelik hayatlarınının tamamını etkilediğine gönderme yapmaktadır. Yani insanlar için beden görünümlerinin değişmesi demek hayatlarının da tamamen değişmesi anlamına gelmektedir. Aşağıdaki örneklerde de bu durum açıkça görülmektedir. 
Taburcu olduktan sonra düzenli olarak kontrollerime gelmeye devam edeceğim ve her kontrolde de yeni vücuduma dolayısıyla da yeni hayatıma bir adım daha yakınlaşmış olacağım (A.T/ 44:27- 44:38).

Doktor B: Çağla çok genç, özgüveni düşük ve ürkek birisi. Estetik cerrahiden beklentisi şeklinin değil hayatının değişmesi (Ç.Ö/ 19:57- 20:05).

En azından özgüvenim yerine geldi gayet mutluyum gerçekten çok mutluyum. Kendimi yeni bir hayata hazır hissediyorum (Y.E.Ç/ 44:30- 44:44).

İlk buraya geldiğimde yine bir tedirginlik vardı bende ama ameliyat sonrası o acının olmaması göğüslerimin olmaması yani yeni doğmuş bir bebek gibiyim şuan (M.A/ 41:0941:13).

M.D(Arkadaşı): O kadar kilo verdikten sonra vücudun artık kendini toparlaması mümkün olmadığı için ameliyat olması gerekiyor ve bu ameliyatını ben de destekliyorum tabi ki olması gerekiyor ve yeni bir hayata başlaması için bu şart (O.C/ 10:14- 10:23).

F.B (Annesi): Çok güzel, çok mutluyum yani umduğumdan daha da güzel çıktı yani bu kadar beklemiyordum harika bir duygu inanılmaz yani anlatılmaz anlatılacak gibi değil yeniden doğdu yani 16 yıl sonra çocuğum yeniden doğdu diyecek bir şey bulamıyorum (A.B/ 34:08- 34:28).

Örneklerde de görüldüğü üzere bireylerin hayatlarının değişmesini sağlayan etken aslında beden görünümleriyle birlikte kimlik tanımlamalarının da değişiyor olmasıdır. Çünkü estetik ameliyatın sonucunda inşa edilmiş bir bedenle birlikte inşa edilmiş bir kimliğe de sahiplik mümkün hale gelmektedir. Programda, "Bu ben miyim?" sorusunun sorulma nedeni ameliyat olan bireylerin aynaya ilk baktıklarında alıştıkları görüntüden farklı bir beden gördüklerine verdikleri tepkinin anlamlandırılmasıdır. Aynadaki ilk karşılaşmada şaşkınlık yaratan yeni beden, beraberinde yeni bir kimlik tanımlamasını da kendiliğinden üretmektedir. Böylece ameliyatlar beden inşasını gerçekleştirdiği oranda katılımcılara yeni bir kimlik de sağlamaktadır. Buradaki kimlik kuşkusuz bireyin toplumsal alandaki konumlandırılmasının değişmesiyle doğrudan ilişkilidir. Aşağıda verilen söylemler de bu bağlama birer örnektir.

Galiba auram bile değiş̧ti bu ameliyattan sonra. Çünkü insanlara olan yaklaşımım ya da insanların bana olan yaklaşımı enteresan bir şekilde değişti. Aynaya baktığım zaman artık eski beni değil yepyeni birini görüyorum (D.T/ 48:15- 48:30).

Bir mucize yani birdenbire dişlerim yapıldı ve ben bambaşka bir insan olarak tekrar doğdum (E.D/ 46:10- 46:20).

Bambaşka olmuşum yani bambaşka Dilek olmuş (D.K/ 27:34- 27:37).

Evime gideyim yeni hayatıma başlayacağım bundan sonra daha farklı bir Dilnoza olacak, daha mutlu daha güzel olacak (D.G/ 46:08- 46:17).

Çok değişik bir duygu aslında insan kendini yeniden doğmuş gibi hissediyor. Kaygılarım, korkularım vardı onlar gitti part time bir işe bile başladım, kendime güvenim geldi (O.C/ 44:36- 44:50).

Bir diğer önemli kriter de programa katılan bireylerin özgüven duygularının beden görünümleri ile doğrudan ilişkili oluşudur. Ameliyat olmadan önce özgüvensiz olan insanlar ameliyat sonrası özgüvenli bir hale gelmektedirler. Aşağıdaki örneklerde bu durum açık bir şekilde görülmektedir.

Biz annemle buraya problemlerimiz vücudumuzda bazı problemler varken geldik belki birazcık özgüven eksikliğimiz varken geldik ama hem özgüvenimiz daha yüksek gidiyoruz hem de daha mutlu gidiyoruz (E.Ö/ 43:20- 43:32).

Her şey çok güzel oldu artık mesleğime de dönebileceğim, özgüvenim yerine geldi (F.A/ 43:02- 43:23). 
Uzun bir süre hiç kilo almadım hep verdim çünkü oradaki o 35 kilonun bana kattığı özgüven çok fazlaydı (D.T/ 11.39- 11:52).

Doktor B: Denizden operasyonla $2 \mathrm{~kg}$ 'dan fazla deri çıkardık bu $2 \mathrm{~kg}$ tartıldığında ona çok fazla bir şey kazandırmayacak ama özgüvenine katkısı çok fazla olacak (D.T/ 36:2036:44).

En çokta kendi psikolojim için benim için çok iyi bir şey oldu kendimi daha özgüvenli hissediyorum (Ö.D/ 43:30- 43:40).

Kendime özgüvenim hiç yoktu yani iş görüşmelerine giderken kendimi güvensiz gidiyordum yani olmayacak gibisinden hep olumsuz düşünüyordum ama şimdi yani öyle bakmıyorum (Ç.Ö/ 15:25- 15:37).

D. Z (Kuzeni): Mehmedin kendine özgüveni çok fazla yok çünkü arkadaş ortamlarında sürekli alay söz konusu oluyor (M.A/ 10:55- 11:05).

Çok özgüvensiz bir insandım otobüse dur diyemediğim için daha önce ya da daha sonra indiğim oluyordu durakta (O.C/ 8:02- 8:25).

A.A (Kuzeni): Beden dersimiz olurdu soyunma odasına gelmezdi çekinirdi, otobüse inerken binerken çekinirdi otobüs iki metre ilerde olsun yani koşup yetişmezdi insanlar bana bakacak diye, özgüveni çok düşük bir çocuktu (O.C/ 8:26- 8:40).

Her şey daha istediğim gibi daha yaşıtlarımla aynı şeyde yürütebileceğim onlardan bir farkım kalmadı artık ben de artık herkes gibiyim onlardan bir eksiğim yok herkeste olması gereken göğüsler artık bende de var çok mutluyum, çok özgüvenliyim (E.M/ 30:16$36: 26)$.

F.T (Arkadaşı): Yani özgüvenini kaybetmiş durumda. Özgüven kaybolduğu zaman biliyorsunuz zaten bunalımlar, sıkıntılar başlıyor bir ara korktum mesela iyice kafayı yemişti, ölmek istiyorum diyordu (T.Ö/ 3:20- 3:29).

Yukarıdaki örneklerde de görüldüğü gibi bireylerin bedenlerine yapılan küçük bir müdahale bile onların kendilerini daha özgüvenli hissetmelerine neden olmaktadır. Aslında özgüven duygusu bir kimlik kriteridir. Bu noktada ameliyat öncesi özgüvensiz bir kimliğe sahip olan bireyler ameliyat sonrası tam zıttı olarak özgüvenli insanlar haline gelmektedirler. Yani aslında kimliği tanımlayan bileşenler de program boyunca karşımıza çıkan söylemlerde görüldüğü üzere değiş̧ime uğramaktadır. Aşağıda verilen söylem bu bağlamla ilişkili olarak değerlendirilmiştir.

İçime kapandım, asosyal bir kız olmaya başladım ve iletişim kurarken diğer insanlarla daha çekinmeye başladım hani insanların içine çıkmaya da çekiniyordum bir süre devamlı saçlarımı önüme alıyordum kimse fark etmesin diye (A.B/ 15:56- 16:10).

$\mathrm{Bu}$ söylemden de anlaşıldığı gibi beğenilmeyen ve başkaları tarafından da beğenildiği düşünülmeyen beden, kişinin özgüvensiz olmasına neden olmakta ve dış çevreye karşı öznenin kişiliğini etkilemektedir. Aynı katılımcı ameliyat olduktan sonra kendi ve yakınlarının söylemi ise şu şekilde olmuştur;

Babası: Bundan sonra çok daha farklı bir Azra ile beraber olacağız öyle düşünüyorum. Çok daha özgüvenli çok daha başarılı olacağını tahmin ediyorum çünkü bu sadece özel hayatını değil derslerine dahi yansıdı her şekilde ama bundan sonra herhalde çok daha başarılı ve özgüvenli olacaktır diye tahmin ediyorum, çok daha farklı bir Azra gelecek (A.B/ 31:36- 32:00).

Öncelikle kesinlikle özgüvenim çok arttı insan içine daha rahatlıkla çıkabiliyorum, birisiyle konuşurken devamlı gülümseyerek konuşuyorum, saçlarımla yüzümü kapatmak zorunda değilim artık aksine hep açıyorum daha çok gülebiliyorum, daha özgüvenli bir şekilde gülüyorum herkesin içinde, korkmuyorum artık gülmekten (A.B/ 44:20- 44:39). 
Örneklerde de görüldüğü gibi bedene yapılan müdahaleden sonra özgüven duygusu da yükselmektedir. Yapılan ameliyatın aslında sadece beden görünümünü etkilemediği kişilik özelliklerini de yeniden oluşturduğu düşüncesi yoğun bir şekilde vardır. Aynı şekilde diğer söylemlerde de bu durum geçerlidir.

Bu ameliyattan sonra daha iyiyim her şey daha güzel oldu, kendime olan özgüvenim geldi, dışarıyla olan bağlantım daha bir pekişti (A.Ç/ 44:09- 44:20).

Gerçekten yeni bir Esra geldi şuan bana. Ya ilk günüm olmasına rağmen kendimi çok iyi, güvende hissediyorum. Bundan sonra daha da özgüveni yerinde olan bir Esra olacağım (E.A/ 35:13- 35:36).

Psikolojikmen kendimi daha iyi hissedeceğim hani bir ortama girdiğim zaman özgüven. Sadece bu fiziksel olarak değil de yani vücudumda fazlalıklar, bu tamamen bir özgüven meselesiydi, bir ortamda her zaman bir adım geri durma meselesiydi benim için şimdi onlar yok tamamen her şeyin içinde ben olacağım ( M.A/ 41:14- 41:40).

Ne olursa olsun dış görünüşünüz sizi her yerde etkiliyor bu sizde bir özgüven eksikliği yaratıyor, hangi ortama girerseniz girin. Artık o özgüven eksikliğinin kalmayacağını düşünüyorum, kendimi güvenli, mutlu bir insan olmayı planlıyorum (G.K/36:05-36:21).

Çok rahatım ameliyat sonrası hiçbir sıkıntım olmadı hatta dışarı çıktığımda daha rahat hissettim hem yürümem değişti daha özgüvenli olduğum için duruşum değişti (E.M/ 44:30- 44:42).

Operasyondan sonra hayatımda çok şey değişti kendime özgüvenim, yok olan özgüvenim geri geldi özellikle burnumu çok beğeniyorum yani hayalimdekinden daha güzel oldu diyebilirim. Artık eski Çağla değilim çünkü önceden içine kapanık özgüvensiz, mutsuz biriydim ama şimdi özgüvenim var mutluyum yani yeniden doğmuş gibi bir şeyim yani (Ç.Ö/ 42:58- 43:20).

Aynı zamanda programa katılan bireyler, beden görünümlerini estetik ameliyatlarla değiştirdiklerinde asıl kişiliklerine ulaştıklarını düşünmektedirler. $\mathrm{Bu}$ değişimle birlikte diğer insanlara karşı da kendilerini yansıtabileceklerini düşünen katılımcılar, böylece yeni bir kimlikle gündelik hayata katılmaktadırlar. Yani insanlar için bedene yapılan müdahale ile aynı süreçte işletilen kimlik inşası onların aslı benliğini yansıtmaktadır. Bu duruma örnek olarak aşağıda verilen söylemler önemlidir.

Yani ben olarak artık var olabilirim. Dediğim gibi daha önceki görüntümde ruhumla bedenim eşleşmiyordu. Şu an kendimi çok iyi hissediyorum (Y.A/ 43:47- 43:57).

Giyinikken istediğim formdaydım, kıyafetlerin arkasına saklanırken ne kadar kendimiz olabiliriz ki esasında (12:10- 12:20). Yani ihtiyacın var mı gerçekten böyle bir şeye ya da ne bileyim zaten yakışıklısın işte biri var işte biri olmasa da olur gibi gibi yorumlar yapabiliyorlar. Ama gerçekten bunu yaşayan biliyor ve ben kendimi bu şekilde huzursuz hissettiğim sürece ne kendimle bir olabiliyorum ne kendimle bütünleşebiliyorum ne de kendimi rahatça ifade edip yansıtabiliyorum. O yüzden bu ameliyatı olabilmem benim için her şeyden daha önemli çünkü artık kendim olmak istiyorum (D.T/ $23: 31$ - 24:16).

Her şeyim değişti ben değiştim, yürüyüşüm değişti, kendim değiş̧tim her şey çok güzel oldu (B.S/ 44:37- 44:46).

Son olarak belirtilmesi gereken nokta, insanlarda beden görünümünün bireylerin kimliklerini yansıttı̆ğ düşüncesi yoğun bir şekilde vardır. Tanımadıkları ya da ilk tanıştıkları insanların kişiliklerini beden görünümleri üzerinden anlamaya çalışmakta ve bir yargıya varmaktadırlar. Programda da bu görüşü destekler nitelikte bazı söylemler mevcuttur. Örneğin;

Ben mülayim bir insanım aslında, çok sakin bir insanım, kavgayla şiddetle asla işim olmaz ve nefret eden bir insanım ama görüntümden dolayı insanlar beni bu şekilde tanıdıkları, lanse ettikleri için hoşuma da gitmiyor (M.Y/ 4:39- 4:51). 
E.Y (Eşi): Kendisinin görünümü dışardan çok agresif, sinirli, kötü görünmesine rağmen asla kişiliğiyle örtüşmeyen bir kişi; tam aksine çok sakin çok mülayim, sinirlerini çok iyi kontrol edebilen bir kişi (M.Y/ 3:39- 3:55).

\section{Bedenin Sergi Değeri}

Beden görünümlerinde beğenmedikleri kısımları olan bireylerde gizlenme ve bu beğenilmeyen kısımla kimseye görünmeme çabası vardır. Programa katılan bireylerde de bu çabanın olduğu açık bir şekilde görülmektedir. Aşağıda verilen söylemler de bu görüşü destekler niteliktedir:

İnsanların olmadığı yerlerde denize giriyorum mesela yani kimse görmesin beni istiyorum ıssız yerlerde ya da kimsenin olmadığı saatlerde girmeye çalışıyorum. Tişörtle girdiğim bile oldu denize mesela (15:41- 15:52). Basketbol oynuyorum normalde ama insanların olmadığı saatlerde giyiniyorum. Vücudumda beğenmediğim yerler olduğu için spor salonunda da soyunma odalarını kullanamıyorum, şu anda sporu da bıraktım o yüzden evde kendim çalışıyorum (A.U/ 16:56- 17:20).

A. A (Kuzeni): Beden dersimiz olurdu soyunma odasına gelmezdi çekinirdi, otobüse inerken binerken çekinirdi otobüs iki metre ilerde olsun yani koşup yetişmezdi insanlar bana bakacak diye, özgüveni çok düşük bir çocuktu (O.C/ 8:26-8:40).

Bireyde görünümünü beğenmemeden kaynaklı ve bedene atfettikleri bir gizlenme değeri yargısı oluşmaktadır. Bireyler bu gizleme değerini çoğunlukla kıyafetleri aracılığıyla pratiğe dökmektedirler. Aşağıdaki söylemlerde de bu durum görülmektedir:

Kıyafetlerimi hep ona göre seçiyorum mesela arkadaşlarımla bir yere gittiğimiz zaman hep sorarım belli oluyor mu diye eğer yakın arkadaşımsa (E.Ö/ 5:07- 5:12).

Dört yıldır korseyle yaşar oldum. Çekmecede kıyafetten çok korse biriktirdim. Kendimi gizleme isteği o kadar çok beni etki altına almıştı ki artık korsesiz yaşayamaz bir hale geldim (E.A/ 5:54- 6:06).

Ayaklarımı hep saklardım. Yazın bile çorap giyerdim (Y.D/ 2:00- 2:05).

Havuza gideceğim gidemiyorum, işte spor yapacağım bir şeyler giyeceğim koca koca artık böyle oversize tarz şeyler giymeye başladım ki ben ufak tefek bir kadınım bugüne kadar hep daracık minicik şeyler giydim. Şimdi bol şeyler giymeye çalışıyorum. Koyu renk seviyordum ama şimdi işte eşimin neredeyse tişörtleriyle gezeceğim (Y.A/ 7:438:05).

Bahsedilen bu gizlenme değeri bireylerin sosyal yaşamlarını da etkilemektedir. Bireylerdeki gizlenme isteği başka insanlarla bir araya geldiklerinde oluşmaktadır. Bu durum ise bireylerin hem diğer insanlarla sağlıklı iletişim kurmasını hem de kendi hayatlarını olumsuz yönde etkilemektedir. Verilen örneklerde de bu durum açık bir şekilde görülmektedir:

Derslerim çok iyiydi benim. Ortaokula yazdırmaya karar verdi babam beni Turhal'a gittik orda yazdırırken baktım kızlar hep etek giymiş o yüzden okulu bıraktım sırf onlar etek giyiyor diye bacaklarım görünecek ve ayaklarım görünecek diyerek. Okul hayatımı da böylece sonlandırdım (2:07- 2:25). Kimseyle çıkmak istemiyordum birisiyle işte görüşsem çıksam veya dünür gelseler falan hep böyle ayaklarımı saklamak ihtiyacı hissediyordum. Çok kötüydü çok kötü günler geçirdim yani. Çok isyan ediyordum devamlı ağlıyordum. Bir düğüne gitmek istemiyordum bir yere katılmak istemiyordum, arkadaşlarımla görüşmek istemiyordum (Y.D/ 2:54- 3:18).

Eskiden fark etmeden kendimi baya kısıtlıyormuşum bu konuda vücudumdaki eksikliği bildiğim için hep kalabalık ortamlardan sosyal ortamlardan kaçıyormuşum şimdi sergiler olsun, sinema olsun alışveriş merkezleri olsun nereyi görürsem geziyorum (E.M/ 44:3244:55). 
Daha önce de ifade edildiği üzere bireylerdeki bu gizlenme isteği beden görünümlerindeki beğenmedikleri kısımlardan kaynaklanmaktadır. Öte taraftan vücuda yapılan müdahalelerle yani estetik ameliyatlarıyla birlikte bireylerdeki bu gizlenme isteği de kaybolmaktadır. Bu bağlamda aşağıda örnekler verilmektedir:

Normalde de zaten hani özgüveni yüksek biriydim. Sadece bazı şeyleri saklama gereği duyuyordum, şekil bozukluğumdan dolayı ya da mesela filtre kullanmayacağım artık. Yani o şekil bozukluğunu filtreyle düzeltmeye çalışıyordum artık filtre yok hayatımda (Y.Ö/ 43:32- 43:51).

İnsanın vücudunda saklamak zorunda kalmadığı bir yeri olmaması çok rahatlatıcı bir şey, kendimi çok rahat hissediyorum ve özgüvenli hissediyorum şuanda daha çok. İstediğim yerde basketbol oynaya biliyorum ve denize girmek istiyorum biran önce yaz gelsin ve denize girmek istiyorum. Rahatça soyunabiliyorum ve spor salonlarında sıkıntı yaşamıyorum soyunma odalarında. Bir yere kendimi saklamak için uğraşmıyorum yani olduğum gibi görünüyorum rahat rahat, sıkıntı yaşamıyorum, mutluyum (A.U/ 24:4725:15).

Artık spor salonuna gittiğim zaman saklamam gereken hiçbir şey yok çünkü eskiden spora giderken acaba salon boş mu ne bileyim soyunma odasında birileri var mı gizlenmek gibi bir kaygım vardı. Çünkü saklamak istediğim ve saklamam gerektiğini düşündüğüm fazlalıklarım vardı artık böyle bir kaygım yok (D.T/ 47:50- 48.12).

Şimdi rahat rahat denize girebilirim spor yaparken kimse bana bakıyor mu diye içimde bir dert olmayacak artık (Y.E.Ç/ 44:30- 44:37).

Yani basit bir şey olabilir hani bir bikini giymek bunları yapacağım artık bu kaybettiğim zamanı telafi edeceğim bikinimi de giyeceğim, göbeğime piercing de taktıracağım, istediğimi yapacağım (T.Ö/ 43:52- 44:07).

Bireylerdeki gizlenme değeri estetik ameliyatlarla kaybolarak yerini sergi değerine bırakmaktadır. Artık vücuttaki beğenilmeyen kısma müdahale yapılmış ve herkesçe onaylanan bir hale getirilmiştir. $\mathrm{Bu}$ nedenden dolayı bireylerde bedenlerini sergileme isteği oluşmaktadır. Aşağıdaki ifadeler bu durumu destekler niteliktedir:

Kalabalık yerlerde denize girmeyi istiyorum şuanda kendimi gösterebilmek için veya hiç tanımadığım insanla gidip sohbet muhabbet etmek istiyorum yargılanmadan, kendim olup (A.U/ 24:20- 24:30).

Eskiden havuza girerken, bikini giyerken ne kadar görünmez olmaya çalışıyorsam şimdi 180 dereceye kadar büyük bir değişimle o kadar görünür olmaya çalışıyorum çünkü çok rahatım, çok özgürüm (A.T/ 49:32- 49.48).

Ay inanmıyorum Doktor B. Harika olmuş. Bu göbeği kimse kapattıramaz artık bana gerçekten. Herkese göstereceğim (Y.A/ 42:16- 42:32).

Artık bütün objektifler bana dönük olabilir çünkü daha önce fotoğraf çektirmeyi hiç seven bir insan değildim, olamadım ama şu an bugün büyük bir fotoğraf arşivim oldu mükemmeldi (E.K/ 45:18- 45:25).

Yukarıdaki ifadelerde görüldüğü üzere ameliyat sonrası süreç bireyler için kusurlarından arındırılmış bedenin sergilenmesi ile tamamlanmaktadır. Bireylerde oluşan bu sergi değeri beraberinde alışveriş yapma, tatile çıkma gibi istekleri de getirmektedir. Yapılan estetik ameliyatlar sonrasında insanlarda yeni kıyafetler satın alma gibi ekonomik davranışlar ortaya çıkmaktadır. Aşağıdaki söylemlerde bu durum açık bir şekilde görülmektedir:

Özellikle yaz aklıma geldiği zaman elbise de giyebileceğim, şort giyeceğim, çeşit çeşit etekler giyeceğim işte deniz kenarında istediğim etekle gezeceğim hatta şimdiden yazlık elbiselere bakmaya başladım. Kendimi hemen kışlık eteklerden aldım. Değişik değişik parçalar aldım (S.Ö/ 50:05- 50:19). 
İlk olarak tatile çıkmayı düşünüyorum avşa adasında çok güzel bir yer var oraya gitmeyi düşünüyorum. Daha sonra iç çamaşırı, gömlek almak hani bunları almayı düşünüyorum (T.D/ 38:57- 39:09).

Alışveriş yapmayı iple çekiyorum, yazın denize gitmeyi, havuza gitmeyi iple çekiyorum, mezuniyetimi iple çekiyorum, güzel elbiseleri deneyeceğim günleri iple çekiyorum (E.M/ 36:00- 36:10).

\section{Bedenin Damgalanma Biçimleri}

İnsanlar sosyal yaşamlarında beden görüntüleriyle bazı değerlendirmelere tabi tutulup önyargılarla karşılaşabilmektedirler. Bu süreçte bireyler kişilik özellikleriyle hiç uyuşmayan damgalamalarla da karşılaşılmaktadır. Programdaki bu duruma örnek ifadeler şu şekildedir:

Y.Y(Oğlu): Onun görüntüsü hakkında korkuyorlar ama ben alıştığım için ya da küçüklüğümden beri onu tanıdığım için bana hiç böyle gelmiyor. Hani bunu dışarıda da öyle mesela babamla yürüdüğüm zaman insanlar korkuyorlar, bu adam sürekli kavga ettiğini falan sanıyorlar ama aslında öyle değil, çok sakin yani aklınızın ucundan bile geçmeyecek kadar sakin ve çok rahat bir insan (M.Y/ 4:52- 5:13).

Mesela trafikte ben ya da karşı taraf hata yaptığı zaman bazen önüme kırıp kavga etmek isteyenler oluyor beni gördükleri zaman çekilip özür dileyip giden insanlar var korktukları için. $\mathrm{Bu}$ olaylarda da ben dış görünüşümle insanları tedirgin etmek, korkutmakta istemiyorum (M.Y/ 7:09- 7:27).

O dikişler alındıktan sonra ilk dışarı çıkma maceralarımdan bir tanesi vardır mesela, çocuğun biri dedi ki a kıza bak faça atmış. Ya bu da mesela insanın canını yakan bir şey, insanlar böyle bilip bilmeden karşılarında gördükleri insanlar hakkında konuşurken birazcık dikkat etmeliler diye düşünüyorum ya karşısındaki insanın ne yaşadığını bilmiyor o anda (G.K/ 18:06-18:31).

Yukarıdaki örneklerde de görüldüğü gibi bireyler beden görünümleriyle değerlendirilip damgalanmaktadırlar. Bu damgalama süreci genel olarak bireylerin dış görünüşleri üzerinden bazı lakaplarla anılmaları ve alay edilmeleriyle somutlaşmaktadır. Bu durumu ifade eden örnekler aşağıda verilmişsir:

Göbek sarkıyor işte göğüslerim sarkık görünüyor. Hani artık eşimde dalga geçmeye başladı işte bak vücuduna bak seksenlik nine gibisin (D.G/ 3:02- 3:12).

B.G (Eşi): Dilnozayı ben işin açıkçası bu haliyle hiç beğenmiyorum. Otuzlu yaşlardayız ama eşim yaşlı yetmişlik nineler gibi vücuda sahip (D.G/ 3:12- 3:22).

Yani bana hep hastalıklı birisi gibi durduğumu söylüyordu daha çok bir iskelet torbası gibi durduğumu söylüyordu ve hatta benim için en büyük en kırıcı olan benzetmesi anneannesine olan benzetmesiyle ilgiliydi (A.T / 23:15 - 23:40).

Küçükken okula giderken bildiğiniz gibi önlük, forma şeklinde kıyafetlerimiz oluyordu ve ben etek giyerek okula gittiğimde arkadaşlarım tabi herhalde hem çocukların acımasızlığı empati yapamamaları nedeniyle hem de diğer kızlardan farklı görmeleri nedeniyle bacaklarımı bir alay konusu olmuştum işte çırpı bacak çöp bacak, fasulye sırığı, kürdan bacak çeşitli tabirlerle benimle alay ediyorlardı (16:42- 17:10). Ben artık diğer insanlar karşısında böyle çöp bacak Sibel diye anılmak istemiyorum (S.Ö/ 19:49- 19: 54).

Anneannesi: Nasıl şişti biliyor musun "bir hilkat garibesi gibi oldu Elif” (E.Ö/ 2:182:22).

Tombik mi demediler dobişko mu demediler yani çok herkes bir şey söylüyordu (G.S/ 15:14- 15:20).

Benim adım kepçe kulak değil kuzu kulak değil benim adım Uygar (U.Ü/ 13:23- 13:30). 
Arkadaşlarım bana topal diye bağırırlardı çok zoruma giderdi okula gitmek istemezdim (1:08- 1:12). İlkokul beşi zorla bitirdim köyde ama hep böyle işte topal, Topal Yaşar, Topal Yaşargül (Y.D/ 1:48- 1:56).

G.C (Annesi): Günden güne sarkmaları çoğaldıkça çarşaf gibi buruşmuş oldu yani etleri çöktü, kolları, göbeği bence kızımın vücudu yaşlı bir insanınkinden daha kötü bir durumda şu an (Y.C/ 11:17- 11:27).

Örneklerde de görüldüğü gibi bireyler beden görünümleri üzerinden sıklıkla lakaplarla anılmatadırlar. Aynı zamanda bireylerin kendileri de görünümlerine bazı lakaplar takıp damgalama yapabilmektedirler. Aşağıda verilen örnekler de bu durumu destekler niteliktedir.

Her şey bitti sanıyordum bundan sonra ben böyle koca göbekli, çirkin göbekli bir kadın olarak devam edeceğim sanıyordum ama bir mucize oldu diyebilirim benim için (Y.A/ 48:58- 49:09).

Bu kendime göre bir yakınlarım, sevenlerim hiçbir zaman öyle söylemese de çırpı olan bacaklarımdan kurtulacağımı düşünmemiştim (S.Ö/ 32:42- 33:58).

Ben çok kilo verdim hocam 30 kilo kadar verdim ya hiçbir şeyim kalmadı aslında tahta gibi oldum. Yani bacaklarım popom kalmadı yüzüm ne bileyim maymun gibi falan hissediyorum herhalde kendimi böyle çökmüş hissediyorum (B.Ç/ 9:37- 9:59).

25 yaşındayım ve kendimi gerçekten sönmüş bir balon gibi hissediyorum (E.A/ 1:29$1: 32$ ).

Çok güzel olmuş kollarım o yarasalar gitti ne kadar çirkin duruyorlardı bak (G.S/ 33:1433:20).

Güzel duruyor. İnsan ayağına dönmüşüm sonunda önceden ördek ayak diyordum kendime (Y.D/ 27:43- 27:56).

İğrenç sönmüş balon gibi göğüsleriniz var ve hiçbir şekilde kaba sığmıyor (E.K/ 14:1514:21).

Programa katılan bireylerdeki damgalama işlemi kadınlarda “iyi anne, güzel anne” gibi bazı kalıp söylemlerde de karşımıza çıkmaktadır. Kuşkusuz damgalamanın bu biçimi toplumsal cinsiyet rollerinin de yeniden gündeme gelmesine neden olmaktadır. Annelik üzerinden yürüyen söylemler, toplumsal alanda kadının rolleriyle doğrudan ilişkilidir. Ameliyatla gerçekleşen değişim, kadının olması gereken kimliğine dönüşü temsil etmektedir. Bu durumla ilişkili örnekler aşağıda verilmiştir:

Ben yaşlı bir anne gibiydim hep onların sorunlarıyla ilgilenirken. Onlar büyüdü onların yanında böyle genç bir anne gibi olmak yani arkadaşlarına beni böyle güzel bir anne olarak göstersinler istiyorum (B.Ç/ 37:33- 37:45).

Artık anne olmak istiyorum eşimi çok seviyorum ve anne olmadan öncede elimden gelenin hepsini yapıp güzel bir anne olmak istiyorum çocuğuma, benden utansın istemiyorum (G.K/ 20:07- 20:25).

Benim oğlum yaşamış olsaydı bakımlı bir anneyi çok isterdi gerçekten de çok istiyordu (F.E/ 7:04- 7:10).

\section{Duyguların Yönetimi Olarak Beden}

Beden görünümü insanların duygularını da çok fazla etkilemektedir. Genel anlamda onaylanmış ideal beden görünümüne sahip olmayan bireyler, içine kapanık ve mutsuz bir ruh halindeyken, ideal beden görüntüsüne sahip olan bireyler daha mutlu ve pozitif bir ruh haline sahiptirler. Yani aslında ideal bir bedene sahip olmak program sürecinde mutluluğun önkoşulu olarak gösterilmektedir. Program kapsamında bu görüşü destekler nitelikte örneklere raslamak mümkündür:

Doktor B: Bacaklarındaki fazla deriyi almadan Binnaz’ı mutlu edemeyiz (B.Ç/ 38:1238:14). 
Ben 23 yaşındayım ama yani hiç yaşımı gençliğimi veya işte ne ergenliğimde ne başka yani hiç mutlu olmadım. İnşallah bu ameliyatı olunca ben de mutlu olacağım (Ç.Ö/ 18:2118:32).

Yukarıda da görüleceği üzere bireyin mutlu olması ameliyatlara bağlıdır. Örneğin yukarıdaki söylemde bireyin mutlu olması için ilk olarak bacaklarına müdahale edilmelidir. Benzer şekilde diğer katılımcının söyleminde de mutluluğun ön koşulu için estetik ameliyat gerekmektedir. İncelenen programda aslında tam anlamıyla bir duygu yönetimi söz konusudur. Çünkü bireylerdeki var olan olumsuz duygulara estetik ameliyatları aracılı̆̆ıyla müdahale edilerek yok edilmektedir. Bu görüşü destekler nitelikteki söylem aşağıda verilmiştir:

Doktor B: Yapmaya çalıştığımız şey senin demin kurduğun cümle var ya ben bundan utanıyorum diye ben ameliyatla senin o utanma duygunu yok edeceğim (Ö.D/ 12:25$12: 32$ ).

Programda bir duygu yönetimi söz konusu olduğunu ifade etmek mümkündür. Bu yönetim ise beden görünümü üzerinden gerçekleştirilmektedir. Ameliyat olmadan önce hayatlarının mutsuz bir şekilde geçtiğini iddia eden bireyler ameliyat sonrasında mutlu olduklarını dile getirmektedirler. Çünkü bu bireylerin bedenlerine ameliyatla müdahale edilmiş ve ideal beden görünümü haline getirilmiştir. Bu da bireyleri mutlu etmektedir. Bu görüşü destekleyen söylemler aşağıda verilmiştir. $\mathrm{Bu}$ söylemlerde bireyler öncelikle mevcut beden görünümlerinden memnun olmadıklarını ve mutsuzluklarını dile getirmiş ameliyat sonrasında ise beden görünümleri sayesinde mutlu olduklarını ifade etmişlerdir.

Mutsuzum ya kendimle barışık değilim çünkü. Kendi vücudumla barışık değilim. Kendimi artık böyle bu şekilde kabul edemiyorum (D.G/ 6:32- 6:39).

Kendimi çok seviyorum, yeni vücudumu çok seviyorum ve çok çok mutluyum (D.G/ 53:56- 54:03).

Yani bu gerçekten beni çok mutsuz etmeye başladı (Y.A/ 7:39- 7:43).

Korku, endişe ve koca bir göbekle geldim şimdi mutlu, hayallerine kavuşmuş ve fit ve genç bir kadın olarak çıkıyorum hastaneden. Kendimi çok iyi hissediyorum, ağrım sızım vs. yok hani çok az. Bu kadarını gerçekten beklemiyordum. Yani enerjim çok yüksek. Kendimi çok mutlu hissediyorum. Çok pozitif ve genç hissediyorum (Y.A/ 42:45- 43:18).

Çocukluğuma döndüğümde hep şunu düşünüyorum doğmamayı çok isterdim. Çünkü bu yaşadığım hayatı sevmiyorum. Kocaman izlerim var ve kocaman bir gözüm var gerçekten hiç mutlu değilim ama gerçekten hiç mutlu değilim (A.Ç/ 15:56- 16:11).

Bir ameliyatla bir operasyonla yüzümün bu kadar toparlaması ve bu kadar güzel bir göbeğe sahip olmak inanılmaz yani gerçekten çok mutluyum (A.Ç/ 34:06- 34:14).

$\mathrm{Bu}$ beni çok mutsuz ve agresif bir hale getirdi. Kendimden mutlu değilim (E.A/ 1:44$1: 50)$.

Çok mutluyum gerçekten çok mutluyum yani anlatılamaz bir şey bu (E.A/ 35:13- 35:17).

Dışarıda aldığı tepkiler ya da kişilerin ön yargılarından ziyade o da kendini mutsuz hissediyor (M.Y/ 4:28- 4:35).

Bilgisayarda gördüğüm görüntü çok mutlu etti ona yakın bile olsa çok daha mutlu olacağım (M.Y/ 23:25- 23:35).

Yukarıdaki programa katılan beş kişinin söyleminden de anlaşıldığı üzere ilk önce beden görünümlerinden kaynaklı bir mutsuzluk duygusu yaşanmaktadır. Yani bedene yapılan müdahale sayesinde insanların duyguları da kontrol altına alınmaktadır. Bu durumdan da beden görünümünün tek boyutlu bir etkisi olmadığ 1 tam aksine insanlarının yaşamına çok boyutlu etkisi olduğu anlaşılmaktadır. 


\section{Sonuç}

Televizyon mutlak gücünü korumaya devam etmektedir. Televizyonu bu kadar güçlü kılan temel faktörlerden birisi programlarının geniş kitleleri etkilemeye devam edişidir. Bu çalışmaya konu olması bakımından Doktor B.'nin böyle bir formatı olduğu görülmektedir. Doktor B. aynı zamanda televizyonun dönüşen yüzüne de gönderme yapması açısından önemlidir. Kuşkusuz dijitalleşme, televizyonu bir mutanta dönüştüren temel süreçken, televizyon da öznesini simulakr özneye dönüştürmektedir. Burada simulakr özne, ben kimim sorusuna verdiği değişken yanıtlarla gündeme gelmektedir. Simulakr özne, dijital alanın aktif öznesidir ve sürekli kendisini yeniden inşa etme gücüne sahiptir. Doktor B.'nin öznesini simulakr özne yapan şeyse bedeni üzerinde istediği değişiklikleri yapabilme gücüne ve özgürlüğüne sahip oluşudur. Bilgisayar programında nasıl olacağı kendisine gösterilen öznenin konumu, akıllı telefonunda çektiği fotoğrafi üzerinde oynamalar yaparak değiştiren özneyle aynıdır. Birisi estetik ameliyatların aktif faili iken, diğeri pasif olmakla birlikte sosyal medyanın dönüştürdüğü kimlikleri temsil eden güçlü bir modüldür. $\mathrm{Bu}$ çalışma, $\mathrm{Bu}$ Ben Miyim? (Doktor B.) programını incelemiştir. İncelerken simulakr özne kavramı kullanılmış ve dijitalleşmenin ilkelerinin gündelik hayatı nasıl etkilediğine odaklanılmıştır. Çalışmada Doktor B. bir söylem metni olarak kabul edilmiş ve söylem analizine tabi tutulmuştur. Bu analizde ortaya çıkan temel başlıkların altını şu şekilde çizmek mümkündür.

"Bu Ben Miyim? (Doktor B)" adlı televizyon programına katılan bireylerin ideal beden görünümüne dönük söylemleri; ideal ve kusursuz beden tanımları, ideal beden görünümüne ulaşmak amacıyla bedene/sağlığa zarar verilmesi ve beden üzerinden toplumsal cinsiyet rollerine atıf yapılması altbaşlıklarıyla değerlendirilmiştir. Programda kullanılan söylemlerin bütününe bakıldığında ideal beden algısının tek tip olmayıp, her bir katılımcının kendileri için oluşturdukları farklı bir ideal beden algısı bulunduğu görülmüsstür. Fakat bu farklı algılar toplumsal söylemlerden etkilenmekte ve nihai aşamada herkesçe onaylanan ortak bir imaja dönüşmektedir. Programa katılan bireylerin zihinlerinde oluşan ideal beden algısı genellikle kendi bedenlerinde beğenmedikleri ya da eksik gördükleri kısımlar üzerinden tanımlanmaktadır. Bu bağlamdan hareketle "Bu Ben Miyim?" programındaki katılımcıların bireylerin ideal beden görünümü hakkındaki söylemlerinde şu noktaların dikkat çektiği görülmüştür

Programa katılan tüm bireyler sağlı sorunu yaşamakla birlikte güçlü estetik kaygılar da taşımaktadırlar. Örneğin kanser nedeniyle tek göğsü olmayan kadının normal kabul edilen bedene kavuşmak için ameliyatı talep etmesi ya da nefes alabilmek için burun ameliyatı olan erkek katılımcının hem sağlıklı nefes almayı ve hem de güzelleşmeyi talep etmesi aynı bağlamın deşifresidir. Ancak erkek katılımc1, görünümünden dolayı sosyal hayatta yaşadığ zorluklarla gündeme gelmektedir. Katılımcının "ben mutluyum ama insanlar beni kabullenemiyor" söylemi toplumsal alanın katılımcılar üzerinde etkisini göstermesi bakımından önemli bir çıkarımdır. Programa katılan bireylerin özgüven duyguları tamamen beden görünümleri ile bağlantılı bir haldedir. Özgüveni bir kimlik kriteri olarak değerlendirmek mümkündür. Bu bağlamda ameliyat öncesi özgüvensiz olan bireyler ameliyat sonrası özgüvenli insanlar olmaktadırlar. Ameliyat bireylerin toplumsal konumlarını yeniden tanımlamaktadır. Çalışmanın bu bölümünde ortaya çıkan temel bağlam aslında kimlik kriterlerinin değiştiğinin görülmesidir. Dolayısıyla özgüven beden görünümüyle bağlantılı olarak değiş̧iyorsa kimlik özellikleri de beden görünümüne bağlı olarak değişebilmektedir. Böylece yeni bir kimlik inşası beden üzerinden gerçekleşmektedir.

Veri analizlerinde toplumsal cinsiyetle ilişkili güçlü argümanlar bulunmaktadır. Kadın olmak için toplumca kabullenilmiş olan kadın görünümüne sahip olmak gerekmektedir. Yani sadece cinsiyet olarak kadın olmak yeterli değil aynı zamanda bel kıvrımına, kalça kıvrımına da sahip olmak gerekmektedir. Programa katılan erkeklerden birçoğu görünümlerinin kadın bedenine benzediğinden şikâyetçi olurken aynı şekilde birçok kadın da görünümlerinin erkek bedenine benzemesinden rahatsızdırlar. Yani aslında erkek ve kadınların beden şekilleri net bir şekilde toplum tarafından 
belirlenmiş ve birbirinden ayrılmıştır. Bu ayrımı yeterince oluşturamayan bedenler ise ideal erkek ve ideal kadın bedeni görünümlerini bozmaktadır. Beden üzerinden kadınların yaşadıkları bir diğer sorunsal da kendilerini yetersiz yani eksik hissetmeleridir. Bu eksik hissetmenin temel nedeni de kendi bedenlerini ideal olarak belirlenmiş beden kalıplarından uzak görmeleridir. Dolayısıyla kadınların hem eşlerine hem de çocuklarına karşı kendilerini kötü hissettiklerini belirtmek mümkündür. Bu kayg1 sonucunda kendilerinin "tam olarak anne" veya "tam olarak eş" kavramlarını dolduramadıklarını düşündükleri görülmektedir.

Bireyler beden görünümleriyle değerlendirilip damgalanmaktadırlar. Bu damgalama süreci genel olarak bireylerin dış görünüşleri üzerinden bazı lakaplarla anılmaları ve alay edilmeleriyle somutlaşmaktadır. Bireylerin söylemlerinde sıklıkla “yaşlı gibi” ifadesi karşımıza çıkmıştır. İnsanları genç yaşta, yaşlı görünümünde olmak tedirgin etmekte, çünkü yaşl1lık istenilen değil ertelenmesi gereken bir gerçeklik olarak inşa edilmektedir. Veri analizlerinde bu kabulle ilişkili bir diğer sonuç ise bedene yapılan cerrahi müdahalenin insanların hayatlarını her zaman olumlu yönde etkileyeceği düşüncesi yaygındır. İnsanlar ameliyatların sonunda beden görünümleriyle birlikte hayatlarının da değişeceğini düşünmektedirler. İki kişi görüntüleri o şekilde olsa da kendilerince mutlu olduklarını ama insanların bunu kabullenemediklerini belirtmiştir. Bu durum da aslında bedenle ilgili tutumlara toplumun etkisinin oldukça güçlü olduğunu göstermektedir.

Bu ben miyim? Sorusunun sorulma nedeni ameliyat olan bireylerin aynaya ilk baktıklarında alıştıkları görüntüden farklı bir görüntü yani beden görmeleridir. Bu aynada ilk karşılaştıklarında sahibinde bile şaşkınlık oluşturan yeni beden, beraberinde yeni bir kimliği de getirmektedir. Yani aslında ameliyatlar beden inşasını gerçekleştirdiği kadar kimlik inşasını da gerçekleştirmektedir. Beden görünümlerinde beğenmedikleri kısımları olan bireylerde gizlenme ve bu beğenilmeyen kısımla kimseye görünmeme çabası vardır. Bahsedilen bu gizlenme değeri bireylerin sosyal yaşamlarını da etkilemektedir. Çünkü bireylerdeki gizlenme isteği başka insanlarla bir araya geldiklerinde oluşmaktadır. Bu durum ise bireylerin hem diğer insanlarla sağlıklı iletişim kurmasını hem de kendi hayatlarını olumsuz yönde etkilemektedir. Beden görünümü insanların duygularını da çok fazla etkilemektedir. Genel anlamda onaylanmış ideal beden görünümüne sahip olmayan bireyler, içine kapanık ve mutsuz bir ruh halindeyken, ideal beden görüntüsüne sahip olan bireyler daha mutlu ve pozitif bir ruh haline sahiptirler. Yani aslında ideal bir bedene sahip olmak program sürecinde mutluluğun önkoşulu olarak gösterilmektedir.

\section{Kaynakça}

Akçay, A. (2004). "Beden”, Felsefe ansiklopedisi, ed. Ahmet Cevizci, ss. 231-237, Etik Yayınları.

Akkaş, C., Bakırtaş, H. \& Çiftçi, S. (2020). Narsistagram: Instagram kullanımında narsisizm. Selçuk İletişim, 13(1), 130-157.

Alanka, Ö. \& Cezik, A. (2016). Dijital kibir: Sosyal medyadaki narsistik ritüellere ilişkin bir inceleme. TRT Akademi (Dijital Medya Sayısi), 1(2), 548-569.

Atay, T. (2017). Görünüyorum o halde varım. Meşhuriyet çağında kültür ve insan. Can Yayınları.

Avcıoğlu, G. Ş. (2011). Yapısal kimlikten seçimlik kimliğine; kimliğin medya aracılığıyla yeniden üretimi. Uluslararası Insan Bilimleri Dergisi, 8 (2), 359-370.

Baudrillard, J. (1981). Simülakrlar ve simülasyon, (Çev. Oğuz Adanır). Doğu Bat1 Yayınları.

Bauman, Z. (2019). Kimlik, (Çev. Mesut Hazır), Heretik Yayınları.

Bell, P. (2001). Content analysis of visual images. T. Leeuwen \& C. Jewitt (Ed.), Handbook of Visual Analysis. London: Sage. 
Bennett, A. (2018). Kültür ve gündelik hayat, (Çev. Nagehan Tokdoğan vd.). Phoenix Yayınevi.

Beyazyüz, M. \& Göka, E. (2015). "Psikoloji ve tıp açısından beden", iç: Beden Sosyolojisi (edt. Kadir Canatan). Aç1lım Kitap, 371-393.

Bilgin, N. (1999). Sosyal psikolojide yöntem ve pratik çalışmalar. Ege Üniversitesi Edebiyat Fakültesi Yayınları.

Bilgin, R. (2016). Geleneksel ve modern toplumda kadın bedeni ve cinselliği. Firat Üniversitesi Sosyal Bilimler Dergisi, 26 (1), 219-243.

Bingöl, O. (2017). Bedenin sosyolojisi: Nasıl? niçin?. Mavi Atlas, 5(1), 86-96.

Bock, P. K. (2001). Insan davranışının kültürel temelleri: Psikolojik antropoloji. (Çev. N. Serpil Altuntek). İmge Kitabevi.

Buffardi, L. E. \& Campbell, K. E. (2008). Narcissism and social networking web sites. Personality and Social Psychology Bulletin, (34), 1303-1314.

Canatan, K. (2015). Çă̆daş toplumlarda ve kültürlerde yaşlılık algıları. Açılım Kitap.

Carpenter, C. J. (2012). Narcissim on Facebook: Self-promotion and anti-social behavior. Personality \& Individual Differences, (52), 482-486.

Castells, M. (2016). İletişim gücü, (Çev. Ebru Kılıç). Bilgi Üniversitesi Yayınları.

Cirhinlioğlu, Z. \& Cirhinlioğlu, F.G. (2015). Postmodern sağlığın yükselişi ve düşüşü. İç: Beden Sosyolojisi (edt. Kadir Canatan). Açılım Kitap, 395-411.

Connell, R. W. (1998). Toplumsal cinsiyet ve iktidar, (Çev. Cem Soydemir). Ayrıntı Yayınları.

Crary, J. (2015). Gözlemcinin teknikleri/on dokuzuncu yüzyllda görme ve modernite (Çev: Elif Daldeniz). Metis Yayınları.

Çakı, F. (2015). "Batı dışı toplumlarda gençlik ve beden imajı", Içc: Beden Sosyolojisi (edt. Kadir Canatan). Aç1lım Kitap, 307-323.

Çaycı, B., Çaycı, A. E. \& Eken, İ. (2019). "Narsisizm ve selfie paylaşımı ilişkisi üzerine nicel bir araştırma". Akdeniz İletişim Dergisi, 31, 60-88.

Çizmeci, E. \& Güzel, E. (2018). Filtreli güzellik. Postiga Yayınları.

Debord, G. (2019). Gösteri toplumu, (Çev. Ayşen Ekmekçi ve Okşan Taşkent). Ayrıntı Yayınları.

Deniz, D. (2019). “Güzellik kaygısı". Aydın Toplum ve İnsan Dergisi, (5 (1), 1-8.

Doğan, S. Y. (2010). Tüketim kültüründe kadın bedeninin idealize edilmesine yönelik kadın algılamaları ve tüketim davranışlarıyla ilişkisi. Selçuk Üniversitesi Sosyal Bilimler Enstitüsü Dergisi, 23, 51-59.

Eliade, M. (1991). Kutsal ve dindışı, (Çev. M. Ali Kılıçbay). Gece Yayınları.

Ersöz, A. G. (2010). Tüketim toplumunda 'sıfir beden' söylemi: Neden ve sonuçları üzerine sosyolojik bir değerlendirme. Hacettepe Üniversitesi Edebiyat Fakültesi Dergisi, 27 (2), 37 53.

Featherstone, M. (2013). Postmodernizm ve tüketim kültürü, (Çev. Mehhmet Küçük). Ayrıntı Yayınları.

Foucault, M. (2015). İktidarın gözü, (Çev. Işık Ergüden). Ayrıntı Yayınları.

Giddens, A. (2000). Sosyoloji. (Çev. H. Özel-C. Güzel). Ayraç Yayınları. 
Goffman, E. (2016). Günlük yaşamda benliğin sunumu, (Çev. Barış Cezar). Metis Yayınları.

Gülbahar, Y. \& Alper, A. (2009). Öğretim teknolojileri alanında yapılan araştırmalar konusunda bir içerik analizi. Ankara Üniversitesi Eğitim Bilimler Fakültesi Dergisi, 42 (2), 93-111.

Han, B.C. (2019). Psikopolitika, (Çev. Haluk Barışcan). Metis Yayınları.

Han, B.C. (2017). Şeffaflık toplumu, (Çev. Haluk Barışcan). Metis Yayınları.

İmren, M. (2018). İşte benim kimliğim: Moda ve medyanın kadınların kimlik inşası ve ideal beden söylemlerindeki rolü üzerine. Ahi Evran Üniversitesi Sosyal Bilimler Enstitüsü Dergisi, 4 (1), 103-111.

Kaya, G. \& Usluel, Y. K. (2011). Öğrenme-Öğretme Süreçlerinde Bit Entegrasyonunu Etkileyen Faktörlere Yönelik İçerik Analizi. Buca Eğitim Fakültesi Dergisi, 31, 48-67.

Kızılçelik, S. (2003). Küreselleşme, beden ve şizofreni. Cumhuriyet Üniversitesi Tıp Fakültesi Dergisi, 25 (4), 89-94.

Krippendorff, K. (2018). Content analysis: An introduction to its methodology. New York: Sage Publication.

Lee, J. \& Sung, Y. (2016). Hide and seek: Narcissism and selfie releated behavior. Cyberpsychology Behavior \& Socail Networking, 19(5), 347-351.

Mayring, P. (2009). Qualitative content analysis. Forum qualitative-sozialforschung/forum: qualitative aocial research. Art. 20 1(2), Temmuz 2008, http://nbnresolving.de/urn:nbn:de:0114-fqs0002204 (Erişim Tarihi: 22 Şubat 2020), 1-10.

Orwell, G. (2019). Boğulmamak için (Çev: Suat Ertüzün), Can Sanat Yayınları.

Oğuz, T. (2016). Çağdaş Narkissoslar: Facebook kullanım alışkanlıkları ve narsissizm. Selçuk Iletişim Dergisi, 9(2), s. 51-68.

Okumuş, E. (2009). Bedene müdahalenin sosyolojisi. Şarkiyat İlmi Araştırmalar Dergisi, 2, 1-15.

Önder, H. T. (2018). "Beden dismorfik bozukluğu”, (Yayın tarihi: 9 Mayıs 2018), http://www.losante.com.tr/Blog/Detail/2084, Erişim Tarihi:20.02.2020.

Özgen, İ. (2017). Tüketim kültürü ve medyada güzellik söylemi: Bir alımlama çalışması. Global Media Journal TR Edition, 8 (15), 1-28.

Özmakas, U. (2018). Biyopolitika: İktidar ve direniş Foucault, Agamben, Hardt-Negri. İletişim Yayınlar1.

Paquet, D. (2015). Bir güzellik öyküsü/ayna ayna, güzel ayna, (Çev. Orçun Türkay). Yapı Kredi Yayınları.

Sağır, A. \& Aktaş, Z. (2019). Simulakr öznenin inşası: Belirsizliklerinden belirliliklere post-truth bir kayma. Abant Kültürel Araştırmalar Dergisi, 4(8), 1-19.

Sarıkaya, A. (2015). 14-18 yaş arası ergenlerin benlik saygısı ve psikolojik dayanıklılık düzeyleri arasındaki ilişki (Yayınlanmamış yüksek lisans tezi). İstanbul Bilim Üniversitesi Sosyal Bilimler Entitüsü.

Sennett, R. (2019). Ten ve taş Batı uygarlığında beden ve şehir, (Çev. Tuncay Birkan). Metis Yayınları.

Solmaz, M. (2018). Egemenliği istemenin yeni bir tarzı: Arzuların kapitalizm tarafindan kışkırtılması. TURKISH STUDIES -International Periodical for the Languages, Literature 
and History of Turkish or Turkic-, ISSN: 1308-2140, Spring 2018, 13(10), http://dx.doi.org/10.7827/TurkishStudies.13529, 617-635.

Sontag, S. (2008). Fotoğraf üzerine, (Çev. Osman Akınhay). Agora Kitaplı̆̆ı.

Soyşekerci, S. (2015). Beden sanatı Rembrant ve anatomi dersleri. Doğu Batı Yayınları.

Tekin, F. (2016). Geleneksel dönemden postmodern döneme beden anlayışının değişimi. TURKISH STUDIES -International Periodical for the Languages, Literature and History of Turkish or Turkic-, ISSN: 1308-2140, (Prof. Dr. Hayati Akyol Armağani), Volume 11/2 Winter 2016, www.turkishstudies.net, http://dx.doi.org/10.7827/TurkishStudies.9351, 1153-1172

Tekin, M. (2015). "Feminizmin kadın algısında beden imgesi ve din". İç: Beden Sosyolojisi (edt. Kadir Canatan). Açılım Kitap, 523-537.

Turner, B. S. (2001). Body and society. Londra: Sage Pub.

Oğuz, G. Y. (2005). Bir güzellik miti olarak incelik ve kadınlarla ilgili beden imgesinin televizyonda sunumu. Selçuk Illetişim, 4(1), 31-37.

Yıldırım, A. \& Demir, Ö. B. (2018). Beden, tıp ve felsefe. Notabene Yayınları. 